\title{
Patch-based survey methods for studying prehistoric human land-use in agriculturally modified landscapes: A case study from the Canal de Navarrés, eastern Spain
}

\author{
Grant Snitker ${ }^{\text {a, * }}$, Agustín Diez Castillo b ${ }^{\text {, C. Michael Barton }}{ }^{\text {c, a }}$, Joan Bernabeu Aubán ${ }^{\text {d, }}$ \\ Oreto García Puchol ${ }^{\mathrm{d}}$, Salvador Pardo-Gordó ${ }^{\mathrm{d}}$ \\ a School of Human Evolution and Social Change, Arizona State University, P.O. Box 872402, Tempe, AZ 85287-2402, USA \\ ${ }^{\mathrm{b}}$ GRAM Research Group in Mediterranean Archaeology, Departament de Prehistòria, Arqueologia i Història Antiga, Universitat de València, Avda. Blasco \\ Ibáñez, 28, 46010 València, Spain \\ ${ }^{c}$ Center for Social Dynamics and Complexity, Arizona State University, 550 E. Orange Street, Tempe, AZ 85287-4804, USA \\ d PREMEDOC Research Group Departament de Prehistòria, Arqueologia i Història Antiga, Universitat de València, Avda. Blasco Ibáñez, 28, 46010 València, \\ Spain
}

\section{A R T I C L E I N F O}

Article history:

Received 19 May 2017

Received in revised form 20 October 2017

Accepted 23 January 2018

Available online $\mathrm{xxx}$

\section{Keywords:}

Off-site methods

Bayesian methods

Digital data collection

Mediterranean basin

Spain

Patch-based survey

\begin{abstract}
A B S T R A C T
In landscapes whose surface has been modified by terracing and other agricultural land-use, the spatial and temporal patterning of prehistoric settlement can be difficult to detect using traditional, siteorientated archaeological survey methods, especially for small-scale societies. In these contexts, methods that can reveal occupational patterns at landscape scales, without the need to pinpoint specific sites of human occupation, can be especially useful. We employ a stratified, randomly selected patchbased survey strategy to examine socio-ecological dynamics from the Middle Paleolithic through Bell Beaker (Chalcolithic) periods within the Canal de Navarrés, eastern Spain. We divide the study region into survey strata according to differences in topography and vegetation communities and use a random selection of demarcated, terraced fields as data collection patches. All survey data is digitally recorded using tablets in the field, creating a streamlined and more accurate workflow, where observations of artifacts, soils, ground visibility, and photographs are georeferenced and ready for analysis in a GIS. Surface artifact densities, estimated from sampled patches, are used to generate prehistoric land-use maps and empirical Bayesian methods allow us to track shifts in occupational patterns through time. Regional reference collections of well-dated lithic artifacts provide the "prior knowledge" required to make estimates of the probability of prehistoric occupation in each sampled patch. This combination of field and analytical methods makes possible the study of regional-scale land-use dynamics in agriculturally modified landscapes.
\end{abstract}

(C) 2018 Elsevier Ltd and INQUA. All rights reserved.

\section{Introduction}

For decades, archaeological survey methods have focused on identifying sites through concentrations of artifacts on the surface of the landscape. But in recent years, research aims have widened beyond sites to include the spatial, temporal, and non-linear interactions between human and ecological systems (Barton et al.,

\footnotetext{
* Corresponding author.

E-mail addresses: gsnitker@asu.edu (G. Snitker), agustin.diez@uv.es (A.D. Castillo), michael.barton@asu.edu (C.M. Barton), juan.bernabeu@uv.es (J.B. Aubán), oreto.garcia@uv.es (O.G. Puchol).
}

1999, 2002; 2004; Carey et al., 2006; Arikan, 2012; Diez Castillo et al., 2016). New social-ecological systems science in archaeology now focuses on multiple types of landscape-scale data, including the continuous distribution of surface artifacts (Dunnell, 1992; Bevan and Conolly, 2002, 2006; Bintliff, 2005). This approach is particularly effective when examining the diachronic interactions between prehistoric land-use, ecological systems, and their influence on landscape evolution (Barton et al., 2004, 2010).

Such a perspective has played a primary role in driving our research over the last three decades in eastern Spain. Survey in the Mediterranean Basin is often stymied by landscapes that have been modified through intensive agricultural land-use, resulting in 
complex palimpsests of archaeological material (Cherry, 1983; Barton et al., 1999; Llobera et al., 2010). We have worked to develop alternative field and analytical approaches that can overcome these challenges. Multiple seasons of fieldwork and experimental methods in the Serpis Valley have resulted in a suite of techniques that consider geomorphology, taphonomy, ground visibility, and relative chronology to evaluate changing patterns of prehistoric land-use (Barton et al., 1999, 2002; 2004; Bernabeu Auban et al., 1999, 2001; 2008; Pardo Gordó et al., 2009, 2015).

As part of Mediterranean Landscape Dynamics Project (MedLanD), a collaborative project between Arizona State University, the University of Valencia, and other organizations, we are now applying the methods developed in the Serpis Valley to a new study area in the Canal de Navarrés, Valencia, Spain. This paper presents our initial results as a case study that examines the challenges and our solutions for evaluating prehistoric land-use in landscapes intensively modified by agricultural terracing. We incorporate patchbased survey methods, digital data collection, and Bayesian statistical methods to systematically evaluate the distribution and intensity prehistoric land-use in this study area.

\section{Regional setting}

\subsection{Environmental setting}

The Canal de Navarrés ( 255 m.a.s.l., $39^{\circ} 06^{\prime} \mathrm{N} 0^{\circ} 41^{\prime} \mathrm{W}$ ) is a flatbottomed, northwest-southeast oriented tectonic valley located at the intersection of the Iberian and Baetic systems in Valencia, eastern Spain (Fig. 1). The valley is circumscribed by three low-lying ranges: the Massís del Caroig to the west, the Serra de Sumacárcer to the east, and the Serra d'Enguera to the south. Tributaries of the Riu Xúquer actively drain this area from both the north and south. Due to tectonic influences and the formation of transverse alluvial fans during the Quaternary, the valley is semiendorheic, resulting in the formation of lakes, peatlands, and travertines throughout the Holocene (La Roca et al., 1996). The modern lakes of Playamonte and l'Albufera d'Anna are evidence of these processes.

This region is situated in the Mesomediterranean belt, a transitional zone between coastal and inland climate zones in eastern Spain. The mean annual temperature is $\sim 16^{\circ} \mathrm{C}$ and the region receives an average annual rainfall of $550 \mathrm{~mm}$. The Mesomediterranean belt experiences typical Mediterranean seasonality, with hot, dry summers and mild, wet winters (Carrión and Van Geel, 1999). Modern vegetation communities consist primarily of matorral species (including Quercus coccifera and Pistacia lentiscus) with some Pinus halepensis in the uplands. In lowland areas, agriculture has replaced most endemic vegetation. Regional palynological studies have revealed multiple fluctuations in vegetation diversity over the last 30,000 years related to global changes in climate (Dupré et al., 1998; Carrión et al., 2010). But the modern distribution and diversity of matorral vegetation may have been influenced by the introduction of fire associated with Neolithic agricultural practices during the middle Holocene (Carrión and Van Geel, 1999), resulting in the replacement of Pinus dominated forests with more fire-tolerant genera such as Quercus, Cistus, and Ulex.

\subsection{Previous archaeological research}

\subsubsection{The Canal de Navarrés}

Archaeological research in the Canal de Navarrés is limited, but current evidence for occupations span from the Middle Paleolithic to the present. Previous work focused on endorheic areas throughout the valley, targeting late Pleistocene and early Holocene occupations. Excavations in the vicinity of Las Fuentes revealed Mousterian lithics and preserved Pinus nigra trunks with radiocarbon dates of more than 40,000 years BP (Aparicio Perez, 1981). Excavations prior to development at another nearby lake, l'Albufera d'Anna, documented geometric lithic forms dating the late Mesolithic (Aparicio Perez, 1973, 1979). The subsequent recovery of pottery remains from l'Albufera d'Anna, indicates a possible Neolithic component (Martí Oliver et al., 2009). Additional evidence of Neolithic occupations is confined to an isolated occurrence of early Neolithic cardial pottery at Covacha de la Bellota (Fletcher Valls and Aparicio Perez, 1970) and the late Neolithic open-air site of Ereta del Pedregal.

Ereta del Pedregal is located within a peatland between the modern communities of Navarrés and Playamonte (Fletcher Valls et al., 1964; Pla Ballester et al., 1983; Juan Cabanilles, 1994, 2008). Initial investigations in the 1940's and later excavations in the 1980 's revealed early examples of stone building construction, a circular stone enclosure, and numerous artifacts. These include lithics and decorated bone associated with Late Neolithic (6000-4500 BP), Chalcolithic (4500-3800 BP), and early Bronze Age (3800-3250 BP) (Pla Ballester et al., 1983). Ereta del Pedregal established the chronology of middle Holocene occupations for the Canal de Navarrés and has been used to interpret the context of other isolated finds throughout the valley.

\subsubsection{Regional archaeological research}

The Canal de Navarrés is comparatively under-studied in contrast to nearby valleys throughout southern Valencia. The regional chronology of Middle Paleolithic (approximately 100,000-30,000 BP) and Upper/Late Upper Paleolithic $(30,000-10,000 \mathrm{BP})$ occupations is reconstructed through welldocumented sites such as El Salt, Cova Beneito, Cova de Parpalló, and Cova de les Cendres (Barton, 1988; Villaverde et al., 1998; RielSalvatore and Barton, 2007; Villaverde Bonilla et al., 2012). Middle Paleolithic chronologies were developed at El Salt and Cova Beneito through a combination of radiocarbon dating and Uranium series dates from travertines underlying occupational contexts. Upper/ Late Upper Paleolithic industries recovered from Cova Beneito, Cova de Parpalló, and Cova de les Cendres have shaped the interpretation of late Pleistocene occupations and chronologies throughout the region (Mallol et al., 2012; Villaverde Bonilla et al., 2012).

Regional Mesolithic and Neolithic chronologies have been built through several decades of systematic excavations in caves, rockshelters, and open-air contexts. Evidence of hunter-gatherer occupations during the Mesolithic (11,000-7600 BP) has been primarily identified through diagnostic lithic technologies, including geometric, triangular/trapezoidal microburins and microliths. Regionally, the early Mesolithic is represented by burials and associated artifacts recovered from El Collado (Garcia Guixé et al., 2006; Gibaja et al., 2015). Important late Mesolithic sites identified throughout the region include Abric de la Falguera (García Puchol and Aura Tortosa, 2006) and Cueva de la Cocina (Fortea Perez, 1971; García Puchol et al., 2009; Bernabeu-Aubán and Martí-Oliver, 2014; García Puchol et al., 2017).

The earliest Neolithic occupations date to $7600-7500 \mathrm{cal}$. BP at multiple sites, including Mas d'Is (Bernabeu Auban et al., 2003), Abric de la Falguera (García Puchol and Aura Tortosa, 2006) and Cova de les Cendres (Bernabeu Auban, 1999; Bernabeu Aubán and Molina Balaguer, 2009). By 6500 cal. BP, cardial ceramics and evidence of domesticated plants and animals were widespread (Sites include Cova d'En Pardo: García Atiénzar, 2009; Cova de l'Or: Martí-Oliver, 2011; Cova de la Sarsa: Garcia Borja et al., 2011). Although excavations in caves and rockshelters have provided reliable ceramic and lithic chronologies for the Valencian Neolithic period, open-air sites such as Mas d'Is (Bernabeu Auban et al., 2003), Niuet (Bernabeu Aubán et al., 1994), Les Jovades (Bernabeu Auban and Badal Garcia, 1992), and Ereta del Pedregal (Fletcher Valls et al., 1964; Pla 


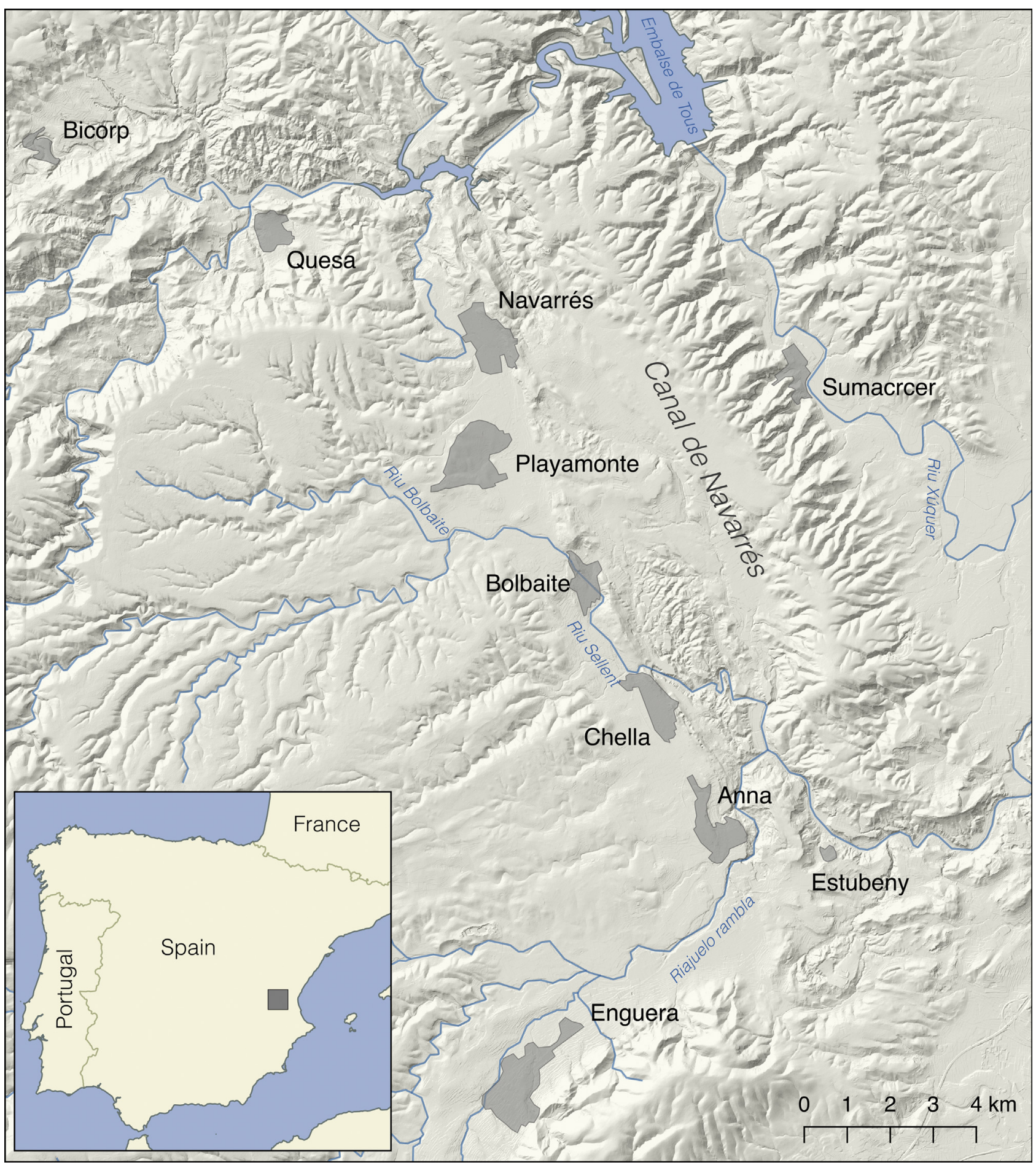

Fig. 1. Overview map of the Canal de Navarrés, Valencia, Spain.

Ballester et al., 1983; Juan Cabanilles, 1994, 2008) offer insights into the changing land-use patterns and social organization that accompanies the Neolithic and Bell Beaker (Chalcolithic) periods.

\section{Material and methods}

\subsection{Off-site survey in the Canal de Navarrés}

\subsubsection{Survey objectives and background}

The primary objective of the Canal de Navarrés archaeological survey is to establish the chronology and intensity of human landuse throughout the valley so we may better understand the changing interaction between social and ecological systems (García Puchol et al., 2014; Diez Castillo et al., 2016). Second, we aim to adapt innovative strategies and analytical techniques to deal with the difficulties of systematic archaeological survey in Mediterranean Basin. Survey projects in the Mediterranean are rare due to several methodological and practical obstacles (Cherry, 1983; Barton et al., 1999). Extensive landscape modification due to agricultural terracing, field delimitation, and water control features 
have redistributed contexts, making chronological interpretations from artifacts difficult. Additionally, complex subdivisions of agricultural land have created a mosaic of walled and terraced fields that vary in ownership from parcel to parcel. Uncultivated areas are often overgrown with thick stands of shrubby vegetation, reducing ground visibility and access. Archaeological survey methods relying on continuous, long transects are often impractical in heavily terraced Mediterranean landscapes.

To address these issues, a series of strategies were developed over several decades of survey in the Serpis Valley, Alicante, Spain. That survey was designed with a patch-based, off-site methodology to evaluate the continuous distribution of human activities across the landscape, rather than focusing on identifying sites (Barton et al., 1999, 2002; Bernabeu Auban et al., 2008). Agricultural terraces across the landscape were not seen as detrimental, but rather as a process through which buried artifacts are exposed on the surface through centuries of tilling, planting, and excavating sediment for terrace construction (Barton et al., 1999). This strategy was effective in evaluating the spatial dimensions of long-term interactions between humans and ecosystems through variations in artifact accumulation and distribution (Barton et al., 2004). Patches without artifacts provide insights into patterns of land-use just as much as those with dense artifact accumulations.

\subsubsection{Adaptation for the Canal de Navarrés survey}

The strategies used in the Serpis Valley were updated and adapted for systematic archaeological survey in the Canal de Navarrés during the 2014 and 2015 field seasons. The project is designed as a stratified, randomly selected pedestrian survey, where the Canal de Navarrés region is divided into survey zones based on topographical features, vegetation communities, and the degree of landscape modification due to agriculture. See Table 1 for descriptions of each zone, stratum designations, and survey coverage. Survey zones are subdivided into survey blocks ("sectors"), which are randomly selected to create sampling strata (Fig. 2). Within each sector, field and parcel boundaries are used to demarcate patches, which we refer to as collection units. Groups of $3-4$ crewmembers walk in transects spaced at approximately $10-\mathrm{m}$ intervals, with some variation to accommodate for cultivated rows in each collection unit (Fig. 3). All encountered artifacts are collected and later washed, identified, and counted in the Department of Prehistory at the University of Valencia (Department of Prehistory, Archaeology, and Antiquity).

Overall, we sampled approximately 25 percent of collection units within each stratum. At the end of the 2014 and 2015 seasons, all zones were sampled with the exception of Zone 8 , which was excluded due to its similarity in topography, vegetation, and modern agricultural land-use to Zone 9 . A small series of collection units outside of the original survey zones were also targeted, non- randomly, in 2015 due to their close proximity to previously known Mesolithic or Neolithic sites. These collections units were labeled as Zone 10. Although not stratified or randomly selected, these collection units helped to pinpoint other areas likely to contain evidence of prehistoric land-use.

\subsubsection{Digital data collection}

All in-field data collection was recorded digitally on tablets, rather than paper forms or maps. Tablets greatly increase the ease and reliability of collecting archaeological data in the field by creating digital back-ups of site data and instantly connecting spatial attributes to field forms. Each survey team was assigned a tablet with custom digital forms created in CartoMobile ${ }^{\circledR}$, a GIS data entry and visualization application for iOS mobile devices. The types of digital data recorded for each collection unit is shown in Table 2. In addition to tablets, each team recorded GPS tracks of survey transects, as required by the Valencian Directorate of Cultural Heritage and Museums.

\subsection{Statistical "unmixing" through Bayesian age estimates of surface assemblages}

One of the challenges facing any archaeological survey is building chronologies using surface assemblages that represent multiple occupational periods or intensities. This problem is exacerbated in Mediterranean landscapes, which are typified by palimpsests of archaeological material created through dynamic erosional regimes and long histories of plowing and terracing. $\mathrm{Ar}$ tifacts spanning the last 100,000 years of human occupation may be found within the same surface contexts. Seriation techniques assume that each assemblage is deposited during a single temporal period and cannot readily accommodate for mixed assemblages.

Bayesian statistical concepts offer an alternative solution for relative chronology building using surface assemblages and explicitly address the palimpsest issue. This approach 'unmixes' surface collections by allowing multiple occupational periods to be simultaneously represented at different probabilities (Buck et al. 1996; Buck and Sahu, 2000; Ortman et al., 2007; FernándezLópez de Pablo and Barton, 2013). Bayesian statistics are a branch of statistical theory developed from the work of Thomas Bayes, an eighteenth-century mathematician. Formally, Bayes' theorem is stated as the following:

$P(H \mid D) \propto P(H) * P(D \mid H)$

in such that the probability of some phenomenon (its posterior probability) $P(H \mid D)$ is proportional to the prior probability $P(H)$ multiplied by the conditional probability $P(D \mid H)$, also known as the likelihood. In other terms, Bayes' theorem provides a means of assessing the probability of an outcome based on the

Table 1

Survey zone descriptions.

\begin{tabular}{|c|c|c|c|c|c|c|c|c|}
\hline Zone & $\begin{array}{l}\text { Num. of } \\
\text { Sectors }\end{array}$ & $\begin{array}{l}\text { Topographic } \\
\text { Landform }\end{array}$ & Dominant Modern Vegetation & $\begin{array}{l}\text { Degree of Modern } \\
\text { Agricultural Land-use }\end{array}$ & Sectors in Survey Stratum & Area of Stratum & Area Surveyed & $\begin{array}{l}\text { Coverage of } \\
\text { Survey Stratum }\end{array}$ \\
\hline 1 & 3 & Lowland & Agricultural & High & $1-1,1-2$ & $3.58 \mathrm{~km}^{2}$ & $0.26 \mathrm{~km}^{2}$ & $7 \%$ \\
\hline 2 & 3 & Lowland & Agricultural & High & $2-2$ & $1.46 \mathrm{~km}^{2}$ & $0.24 \mathrm{~km}^{2}$ & $16 \%$ \\
\hline 3 & 6 & Lowland & Agricultural & High & $3-2,3-3,3-5$ & $5.53 \mathrm{~km}^{2}$ & $0.59 \mathrm{~km}^{2}$ & $11 \%$ \\
\hline 4 & 2 & Transitional & Mixed Agricultural \& Pine Forest & Moderate & $4-1,4-2$ & $3.90 \mathrm{~km}^{2}$ & $0.73 \mathrm{~km}^{2}$ & $19 \%$ \\
\hline 5 & 2 & Transitional & Mixed Agricultural \& Matorral & High & $5-1,5-2$ & $3.10 \mathrm{~km}^{2}$ & $0.49 \mathrm{~km}^{2}$ & $16 \%$ \\
\hline 6 & 3 & Upland & Mixed Agricultural \& Matorral & Moderate & $6-1$ & $1.36 \mathrm{~km}^{2}$ & $0.32 \mathrm{~km}^{2}$ & $24 \%$ \\
\hline 7 & 4 & Upland & Pine Forest & Low & $7-2,7-4$ & $9.60 \mathrm{~km}^{2}$ & $1.00 \mathrm{~km}^{2}$ & $11 \%$ \\
\hline 8 & 3 & Upland & Mixed Agricultural \& Pine Forest & Moderate & - & - & - & - \\
\hline 9 & 6 & Upland & Mixed Agricultural \& Pine Forest & Moderate & $9-6$ & $3.25 \mathrm{~km}^{2}$ & $0.71 \mathrm{~km}^{2}$ & $22 \%$ \\
\hline 10 & - & Transitional & Mixed Agricultural \& Matorral & Moderate & 10 & $0.09 \mathrm{~km}^{2}$ & $0.09 \mathrm{~km}^{2}$ & $100 \%$ \\
\hline
\end{tabular}




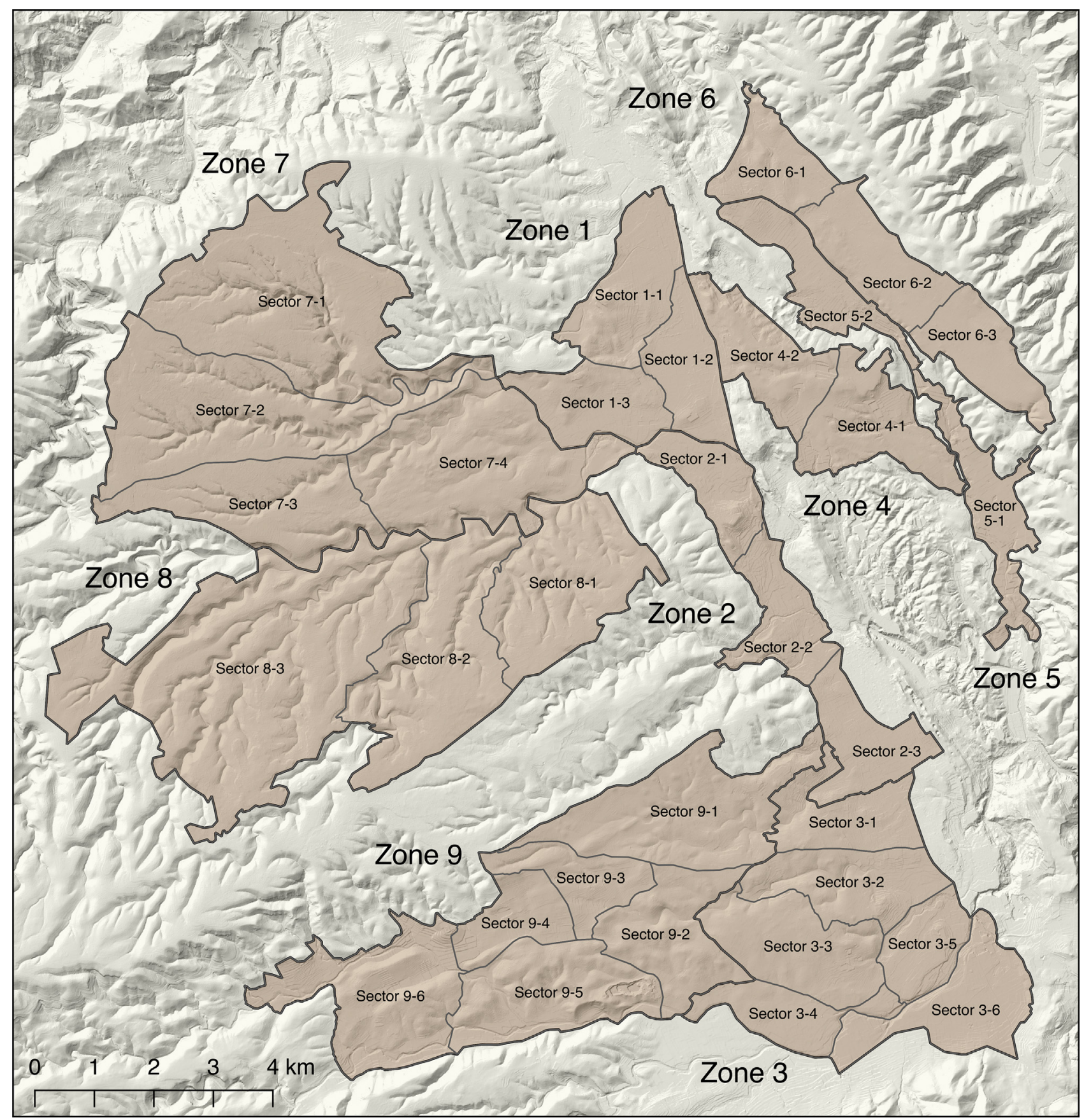

Fig. 2. Survey zones and sectors in the Canal de Navarrés.

combination of new data and prior knowledge about the probability of that outcome. Practically, this perspective provides a systematic method for estimating the age of surface assemblages by incorporating previous knowledge about the association of certain artifact forms with temporal periods. Relying on expert knowledge and experience in archaeology is commonly employed in archaeological projects, but a Bayesian approach allows us to formalize these methods by utilizing a wide variety of published data on regional sites to evaluate our confidence in assigning occupational chronologies to the landscape. See Fernández-López de Pablo and Barton 2013 and Ortman et al., 2007 for more details on Bayesian age estimates for archaeological surface assemblages.

\subsubsection{Calibration dataset based on prior knowledge}

Barton and colleagues (1999, 2002, 2004) developed a Temporal Index (TI) by assigning rank-order probability estimates for specific time periods based on the presence and absence of artifact forms collected during archaeological survey in the Serpis Valley. The present work expands their chronology-building framework by incorporating formalized Bayesian statistics to the presence/ absence data for temporally sensitive artifact forms. We use this approach to estimate the probability that a surface assemblage from a collection unit is associated with one of nine occupational periods in the Canal de Navarrés (including the Middle Paleolithic, Upper Paleolithic, Late Upper Paleolithic, Early Mesolithic, Late Mesolithic, Early Neolithic, Middle Neolithic, Late Neolithic, and 


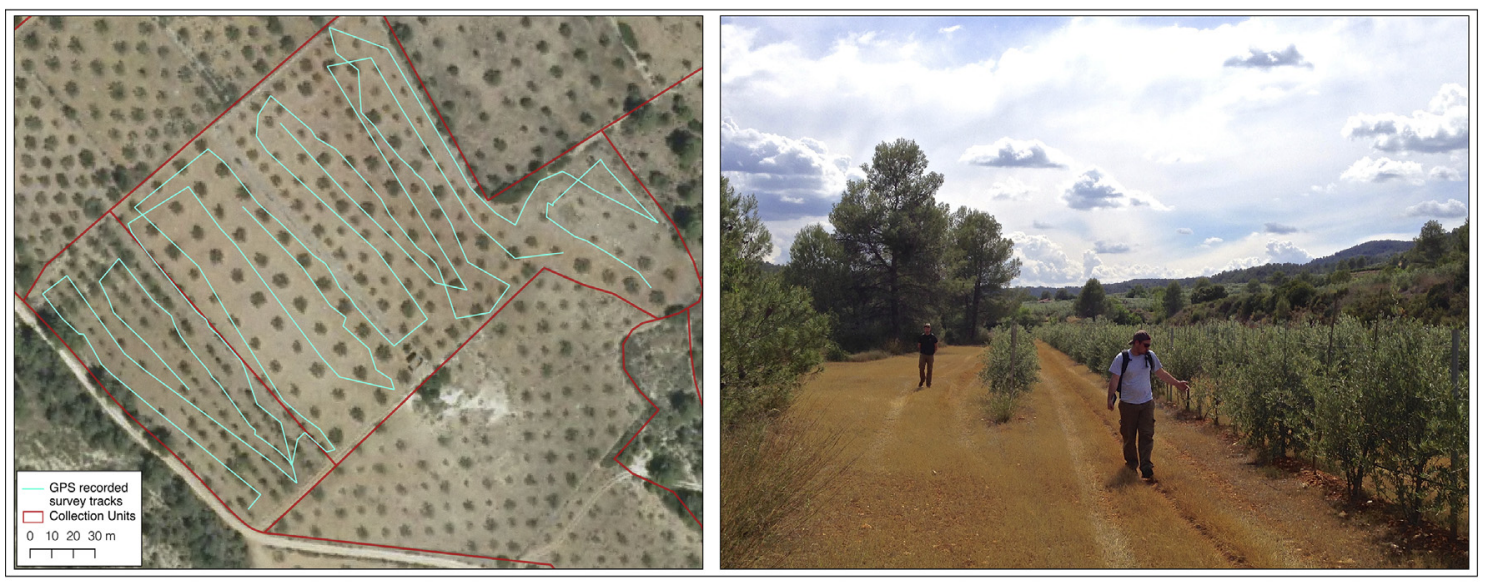

Fig. 3. Example of survey methodology in collection units.

Table 2

Description of digital data recorded for each collection unit.

\begin{tabular}{ll}
\hline Data field & Description \\
\hline Date and time & Timestamp when each collection unit \\
& was recorded \\
Sector & Survey Sector (eg. Sector 5) \\
Subsector & Survey Subsector (eg. Subsector 1) \\
Collection Unit number & Field parcel number (eg. 100263) \\
Ground visibility & Good, Moderate, or Poor \\
Artifacts collected & Yes or No \\
Geospatial information for & Digitized centroid if entire parcel is used as \\
$\quad$ each collection unit & a collection unit; digitized polygon and \\
& centroid if only a partial parcel is used \\
& as a collection unit \\
Photographs of collection unit & Digital photographs detailing the \\
& collection unit, ground visibility, or \\
Additional Notes & notable artifacts \\
\hline
\end{tabular}

Bell Beaker periods). See Table 3 for details on each occupational period.

Other applications of Bayesian methods for dating surface assemblages have relied on independently dated artifact forms from excavated contexts to create calibration datasets and establish prior probabilities for temporal periods (Ortman et al., 2007; FernándezLópez de Pablo and Barton, 2013). Unfortunately, few sites have been excavated in the Canal de Navarrés, and those that have been excavated do not include dated materials that span the entire range of the occupation periods present in this region. Rather than artifacts counts assigned to each chronological period to estimate our prior probabilities, we rely a calibration dataset of presence/ absence data developed from TI measurement of archaeological survey and excavation in the Serpis Valley (Barton et al., 1999, 2004). Presence and absence of 16 lithic forms in each of the nine periods were coded as $1 \mathrm{~s}$ and 0 s, respectively (Table 3 ). Prior probabilities were estimated by calculating the frequency of a particular lithic form relative to all other forms. This is then compared to the relative frequency of that form for each temporal period where it was present. Although ceramics or other temporally sensitive artifact types could provide data for building a calibration dataset, only lithics were recovered from prehistoric contexts in the Canal de Navarrés survey area.

\subsubsection{Posterior probabilities for occupational periods}

Posterior probabilities for each occupational period were calculated based on the frequency of temporally sensitive artifact forms identified in each collection unit from the Canal de Navarrés survey. Following the application of Bayes' theorem from Fernández-López de Pablo and Barton (2013), we calculate the probability that a collection unit dates to one of nine occupational periods, based on specific artifact forms, as follows:

$P\left(m_{i} \mid\right.$ type $\left._{j}\right)=\frac{P\left(m_{i}\right) * \sum_{j=1}^{n} P\left(\text { type }_{j} \mid m_{i}\right)}{\left.\sum_{l=1}^{k} P\left(m_{l}\right)\right)^{*} \sum_{j=1}^{n} P\left(\text { type }_{j} \mid m_{i}\right)}$

where $i=1$ to $k$ are the nine occupational periods in the Canal de Navarrés and $j=1$ to $n$ are the temporally sensitive artifact forms. $P\left(\right.$ type $\left._{j} \mid m_{i}\right)$ is the conditional probability for artifact form type $e_{j}$ and occupational period $m_{i}$, and $\mathrm{P}\left(m_{i}\right)$ is the prior probability of artifact form type $e_{j}$ being represented in occupational period $m_{i}$.

Since prior probabilities for the Canal de Navarrés are based on presence/absence data for each occupational period, additional prior knowledge was introduced in the form of independent weighting of posterior probabilities. This allows us to rely on expert knowledge about artifact forms and their associated occupation periods rather than artifact frequencies from well-dated, excavated contexts. Assemblages from each collection unit were assigned a score between 0 and 6 for each of the nine occupational periods based on combinations of artifact forms, as illustrated in Table 4. Scores for each collection unit where re-scaled to sum to 1 and were multiplied by the posterior probability for each collection unit and occupational period. See Fig. 4 for a conceptual map of this methodology.

\section{Results}

\subsection{Summary of survey results}

\subsubsection{Zone 1}

Zone 1 is located within the municipality of Navarrés and consists of lowland, endorheic areas such as the large karstic upwelling of Las Fuentes. This area is intensively cultivated and irrigated, but terracing remains somewhat limited due to the landscape's low slope. Ereta del Pedregal and Las Fuentes archaeological sites are both located in this zone (Diez Castillo et al., 2016).

Within zone 1 , samples of both sectors $1-1$ and $1-2$ were surveyed during the 2014 and 2015 field seasons (Fig. 5a). Lithic artifacts were recovered in 22 of the 79 collection units surveyed in sector $1-1$ and in 2 of the 4 collection units surveyed in sector $1-2$. In collection unit 1100355, located adjacent to the site of the Ereta 
Table 3

Details on each occupational period and lithic forms used in the Bayesian analysis.

\begin{tabular}{|c|c|c|c|}
\hline Temporal Range & Duration (kyr) & Occupational Period & Attributed Lithic Forms \\
\hline $4500-3800 \mathrm{BP}$ & 0.7 & Bell Beaker & $\begin{array}{l}\text { - Foliate/Bifacial projectile points } \\
\text { - Invasive retouched blades } \\
\text { - Denticulated sickle blades } \\
\text { - Undifferentiated lithics (flakes, chunks, and shatter) }\end{array}$ \\
\hline 6000-4500 BP & 1.5 & Late Neolithic & $\begin{array}{l}\text { - Foliate/Bifacial projectile points } \\
\text { - Triangle microliths } \\
\text { - Trapeze microliths } \\
\text { - Invasive retouched blades } \\
\text { - Retouched blades } \\
\text { - Generic blade technology (blades, bladelets, and blade core preparation) } \\
\text { - Undifferentiated lithics (flakes, chunks, and shatter). }\end{array}$ \\
\hline 6800-6000 ВР & 0.8 & Middle Neolithic & $\begin{array}{l}\text { - Triangle microliths } \\
\text { - Trapeze microliths } \\
\text { - Invasive retouched blades } \\
\text { - Retouched blades } \\
\text { - Generic blade technology (blades, bladelets, and blade core preparation) } \\
\text { - Undifferentiated lithics (flakes, chunks, and shatter). }\end{array}$ \\
\hline 7600-6800 ВР & 0.8 & Early Neolithic & $\begin{array}{l}\text { - Truncated blades } \\
\text { - Triangle microliths } \\
\text { - Trapeze microliths } \\
\text { - Retouched blades } \\
\text { - End scrapers } \\
\text { - Generic blade technology (blades, bladelets, and blade core preparation) } \\
\text { - Undifferentiated lithics (flakes, chunks, and shatter). }\end{array}$ \\
\hline $8600-7600 \mathrm{BP}$ & 1 & Late Mesolithic & $\begin{array}{l}\text { - Truncated blades } \\
\text { - Triangle microliths } \\
\text { - Trapeze microliths } \\
\text { - Backed blades } \\
\text { - Microburins } \\
\text { - End scrapers } \\
\text { - Generic blade technology (blades, bladelets, and blade core preparation) } \\
\text { - Undifferentiated lithics (flakes, chunks, and shatter). }\end{array}$ \\
\hline $11,000-8600 \mathrm{BP}$ & 2.4 & Early Mesolithic & $\begin{array}{l}\text { - Backed blades } \\
\text { - End scrapers } \\
\text { - Generic blade technology (blades, bladelets, and blade core preparation) } \\
\text { - Notches/Denticulates microliths } \\
\text { - Undifferentiated lithics (flakes, chunks, and shatter). }\end{array}$ \\
\hline $13,000-10,000 \mathrm{BP}$ & 3 & Late Upper Paleolithic & $\begin{array}{l}\text { - Backed blades } \\
\text { - End scrapers } \\
\text { - Generic blade technology (blades, bladelets, and blade core preparation) } \\
\text { - Burins } \\
\text { - Undifferentiated lithics (flakes, chunks, and shatter). }\end{array}$ \\
\hline $30,000-13,000 \mathrm{BP}$ & 17 & Upper Paleolithic & $\begin{array}{l}\text { - End scrapers } \\
\text { - Generic blade technology (blades, bladelets, and blade core preparation) } \\
\text { - Burins } \\
\text { - Undifferentiated lithics (flakes, chunks, and shatter). }\end{array}$ \\
\hline $100,000-30,000$ BP & 70 & Middle Paleolithic & $\begin{array}{l}\text { - Discoidal/Levallois Flake Technology } \\
\text { - Mousterian technology (projectile points and side scrapers) } \\
\text { - Notches/Denticulates microliths } \\
\text { - Undifferentiated lithics (flakes, chunks, and shatter). }\end{array}$ \\
\hline
\end{tabular}

del Pedregal, multiple temporally sensitive artifacts were recovered including truncated and laminate blades.

\subsubsection{Zone 2}

Zone 2 is located within the municipality of Chella on the west bank of the Riu Bolbaite within the middle section of the valley. Only sector 2-2 was sampled, resulting in lithic artifacts recovered in 24 of the 99 collection units surveyed. The distribution of artifacts recovered from this portion of the valley suggest that most of the prehistoric record is likely buried under alluvial sediments deposited throughout the Holocene by the Riu Bolbaite and its tributaries (Fig. 5a).

\subsubsection{Zone 3}

Zone 3 is located within the municipality of Anna and encompasses l'Albufera d'Anna, a small lake within the southern end of the endorheic basin that has been improved in recent years for use as a recreation site. This area has also undergone major agricultural and recreational development in the last several decades, resulting in increased erosion and denudation of Holocene sediments. During the 2014 and 2015 field seasons, crewmembers sampled sectors $3-2,3-3$, and 3-5, surveying a total of 113 collection units. Collections were made in 14 units, resulting in a total of 28 lithic artifacts from all of zone 3 (Diez Castillo et al., 2016).

\subsubsection{Zone 4}

Zone 4 is split between the municipalities of Bolbaite and Chella and sectors 4-1 and 4-2 near Chella were sampled for survey. This zone encompasses the western portion of a secondary, adjacent drainage (barranco del Matet) that flows south into the Riu Bolbaite and is positioned in a transitional area between other upland and lowland survey zones. Numerous smaller tributaries have downcut the adjacent limestone hills, creating small ravines and rockshelters. Zone 4 contains Covacha de la Bellota, a small rockshelter from which cardial ceramics were recovered during earlier investigations (Fletcher Valls and Aparicio Perez, 1970). Lithics were 
Table 4

Weight scores for posterior probabilities by presence/absence of artifact forms (adapted from Barton et al., 1999): G1: Trapezes or Triangles; G2: Segments or Rectangles; Sickles: Sickle blades/bladelets; Dent. Sickles Denticulated sickles; Bif. drills: bifacial drill; Nch. and Dent: Notches and denticulated micoliths; Blade Tech.: Blade Technology; Flake Tech.: Discoidal/Levallois flakes; Backed blds.: backed blades/bladelets; End scrp.: endscrapers; Brn: Burins; Must.: Mousterian technology (bifaces and side scrapers); Proj. points: Foliate/bifacial projectile points; Ret. blades: Retouched Blade; Inv. Ret.: Invasive retouched blade; Trc: Truncated blades; M1: Microburins; Labs: Labios engrosados ceramics; BB ceramics: Bell Beaker Campaniforme ceramics; Cardial: Cardial ceramics; Esgr.: Esgrafiada ceramics; Peina: Peina Ceramics; Epi: Ceramics decorated with incisions or impressions.

\begin{tabular}{|c|c|c|c|c|c|c|c|}
\hline & 6 & 5 & 4 & 3 & 2 & 1 & 0 \\
\hline \multirow{3}{*}{$\begin{array}{l}\text { Bell Beaker } \\
\text { (Chalcolithic) } \\
\text { Late Neolithic }\end{array}$} & P: BB ceramics & P: Dent. sickles & P: Proj. points & P: Inv. Ret. + Labs. & P: Inv. Ret. or Labs. & P: Lithics, Ceramics & \multirow{2}{*}{ A: Artifacts } \\
\hline & P: Proj. points + Labs. + Inv. Ret. & $\begin{array}{l}\text { P: Proj. points }+ \text { (Inv. Ret. or } \\
\text { Labs.) }\end{array}$ & $\begin{array}{l}\text { P: Proj. points or Inv. Ret. or } \\
\text { Labs. }\end{array}$ & $\begin{array}{l}\text { P: Blade tech. + (Ret. blades, Bif. } \\
\text { drills, Sickles, Ceramics or G1) }\end{array}$ & $\begin{array}{l}\text { P: Blade tech. + (Ret. blades, Bif. } \\
\text { drills, Sickles, Ceramics or G1) }\end{array}$ & P: Lithics, Ceramics & \\
\hline & A: BB ceramics or Dent. sickles & A: BB ceramics or Dent. sickles & & $\begin{array}{l}\text { A: BB ceramics, Dent. sickles, } \\
\text { Esgr. or Card. }\end{array}$ & & & A: Artifacts \\
\hline \multirow[t]{2}{*}{ Middle Neolithic } & \multirow[t]{2}{*}{ P: Esgr. } & $\begin{array}{l}\text { P: (Inv. Ret or G2)+ (Epi. or } \\
\text { Peina) }\end{array}$ & $\begin{array}{l}\text { P: (Inv. Ret or G2)+ (Epi. or } \\
\text { Peina) }\end{array}$ & $\begin{array}{l}\text { P: Blade tech. + (Ret. blades, } \\
\text { Sickles, Ceramics or G1) }\end{array}$ & $\begin{array}{l}\text { P: Blade tech. + (Ret. blades, Bif. } \\
\text { drills, Sickles, Ceramics or G1) }\end{array}$ & \multirow[t]{2}{*}{ P: Lithics, Ceramics } & \\
\hline & & $\begin{array}{l}\text { A: BB ceramics, Dent. Sickles or } \\
\text { Proj. points }\end{array}$ & & $\begin{array}{l}\text { A: BB ceramics, Dent. sickles, } \\
\text { Proj. points or Card. }\end{array}$ & & & A: Artifacts \\
\hline \multirow[t]{2}{*}{ Early Neolithic } & \multirow[t]{2}{*}{ P: Card. } & $\begin{array}{l}\text { P: Epi + (G1 or Trc) }+ \text { (Ret. } \\
\text { blades, Bif. drills or } \\
\text { Sickles) + (G1 or } \\
\text { Trc }+ \text { + Ceramics }\end{array}$ & $\begin{array}{l}\text { P: Epi+ }(\mathrm{G} 1 \text { or } \operatorname{Trc})+(\text { Ret. } \\
\text { blades, Bif. drills or } \\
\text { Sickles })+(\mathrm{G} 1 \text { or } \operatorname{Trc})+ \\
\text { Ceramics }\end{array}$ & $\begin{array}{l}\text { P: Blade tech. + (Ret. blades, Bif. } \\
\text { Drills, Sickles, Ceramics or G1) }\end{array}$ & $\begin{array}{l}\text { P: Blade tech. + (Ret. blades, Bif. } \\
\text { Drills, Sickles, Ceramics or G1) }\end{array}$ & \multirow[t]{2}{*}{ P: Lithics, Ceramics } & \\
\hline & & $\begin{array}{l}\text { A: BB ceramics, Dent. Sickles, } \\
\text { Proj. points or Esgr, }\end{array}$ & & $\begin{array}{l}\text { A: BB ceramics, Dent. Sickles, } \\
\text { Proj. points or Esgr, }\end{array}$ & & & A: Artifacts \\
\hline \multirow[t]{2}{*}{ Late Mesolithic } & $\begin{array}{l}\text { P: (G1 or M1) + Backed } \\
\text { blds. + (End scrp. or Trc) }\end{array}$ & $\begin{array}{l}\text { P: }(\text { G1 or M1) + End } \\
\text { scrp. }+(\text { (Backed blds. or Trc })\end{array}$ & \multirow[t]{2}{*}{$\begin{array}{l}\text { P: (G1 or M1) + End } \\
\text { scrp. + (Backed blds. or Trc) }\end{array}$} & $\begin{array}{l}\text { P: Blade tech. }+ \text { (G1, Trc or End } \\
\text { scrp.) }\end{array}$ & $\begin{array}{l}\text { P: Blade tech. }+ \text { (G1, Trc or End } \\
\text { scrp.) }\end{array}$ & \multirow[t]{2}{*}{ P: Lithics } & \\
\hline & $\begin{array}{l}\text { A: Ceramics, G2, Sickles, Proj. } \\
\text { points }\end{array}$ & $\begin{array}{l}\text { A: Ceramics, G2, Sickles, Proj. } \\
\text { points }\end{array}$ & & $\begin{array}{l}\text { A: Ceramics, G2, Sickles, Proj. } \\
\text { points }\end{array}$ & & & A: Lithics \\
\hline \multirow[t]{2}{*}{ Early Mesolithic } & $\begin{array}{l}\text { P: Backed blds. + End } \\
\text { scrp. + Nch. and Dent. }\end{array}$ & $\begin{array}{l}\text { P: (Backed blds. or End } \\
\text { scrp.) + Nch. and Dent. }\end{array}$ & \multirow[t]{2}{*}{$\begin{array}{l}\text { P: (Backed blds. or End } \\
\text { scrp.) + Nch. and Dent. }\end{array}$} & $\begin{array}{l}\text { P: Blade tech., End scrp. or } \\
\text { Backed blds. }\end{array}$ & $\begin{array}{l}\text { P: Blade tech., End scrp. or } \\
\text { Backed blds. }\end{array}$ & \multirow[t]{2}{*}{ P: Lithics } & \\
\hline & $\begin{array}{l}\text { A: G1, G2, Sickles, Bif. drills, } \\
\text { Ceramics or Proj. points }\end{array}$ & $\begin{array}{l}\text { A:G1, G2, Sickles, Bif. drills, } \\
\text { Ceramics or Proj. points }\end{array}$ & & $\begin{array}{l}\text { A:G1, G2, Sickles, Bif. drills, } \\
\text { Ceramics or Proj. points }\end{array}$ & & & A: Lithics \\
\hline \multirow[t]{2}{*}{$\begin{array}{l}\text { Late Upper } \\
\text { Paleolithic }\end{array}$} & $\begin{array}{l}\text { P: End scrp. + Brn + Backed } \\
\text { blds. }\end{array}$ & $\begin{array}{l}\text { P: Backed blds.+ (Brn or End } \\
\text { scrp.) }\end{array}$ & \multirow[t]{2}{*}{$\begin{array}{l}\text { P: Backed blds. }+ \text { (Brn or End } \\
\text { scrp.) }\end{array}$} & $\begin{array}{l}\text { P: Blade tech., End scrp, Brn or } \\
\text { Backed blds. }\end{array}$ & $\begin{array}{l}\text { P: Blade tech., End scrp., Brn or } \\
\text { Backed blds. }\end{array}$ & \multirow[t]{2}{*}{ P: Lithics } & \\
\hline & $\begin{array}{l}\text { A: G1, G2, Sickles, Bif. drills, } \\
\text { Ceramics or Proj. points }\end{array}$ & $\begin{array}{l}\text { A: G1, G2, Sickles, Bif. drills, } \\
\text { Ceramics, Proj. points }\end{array}$ & & $\begin{array}{l}\text { A: G1, G2, Sickles, Bif. drills, } \\
\text { Ceramics, Proj. points }\end{array}$ & & & A: Lithics \\
\hline \multirow[t]{2}{*}{ Upper Paleolithic } & P: Blade tech. + End scrp. + Brn & $\begin{array}{l}\text { P: Blade tech. + (End scrp. or } \\
\text { Brn) }\end{array}$ & \multirow[t]{2}{*}{$\begin{array}{l}\text { P: Blade tech. + (End scrp. or } \\
\text { Brn) }\end{array}$} & P: Blade tech., End scrp. or Brn & P: Blade tech., End scrp. or Brn & \multirow[t]{2}{*}{ P: Lithics } & \\
\hline & $\begin{array}{l}\text { A: G1, G2, Sickles, Bif. drills, or } \\
\text { Ceramics }\end{array}$ & $\begin{array}{l}\text { A: G1, G2, Sickles, Bif. Drills, or } \\
\text { Ceramics }\end{array}$ & & $\begin{array}{l}\text { A:G1,G2, Sickles, Bif. drills, or } \\
\text { Ceramics }\end{array}$ & & & A: Lithics \\
\hline \multirow[t]{2}{*}{ Middle Paleolithic } & $\begin{array}{l}\text { P: Flake tech. + Nch. and } \\
\text { Dent. + Must. }\end{array}$ & $\begin{array}{l}\text { P: Flake tech.+ (Must. or Nch. } \\
\text { and Dent.) }\end{array}$ & \multirow[t]{2}{*}{$\begin{array}{l}\text { P: Flake tech.+ (Must or Nch. } \\
\text { and Dent.) }\end{array}$} & P: Flake tech. or Must. & P: Flake tech. or Must. & \multirow[t]{2}{*}{ P: Lithics } & \\
\hline & $\begin{array}{l}\text { A: Ceramics, Blade tech., or Proj. } \\
\text { points. }\end{array}$ & $\begin{array}{l}\text { A: Ceramics, Blade tech., or Proj. } \\
\text { points. }\end{array}$ & & $\begin{array}{l}\text { A: Ceramics, Blade tech., or Proj. } \\
\text { points. }\end{array}$ & & & A: Lithics \\
\hline
\end{tabular}


Archaeological Survey

Lithic Analysis

Application of
Bayesian Methods

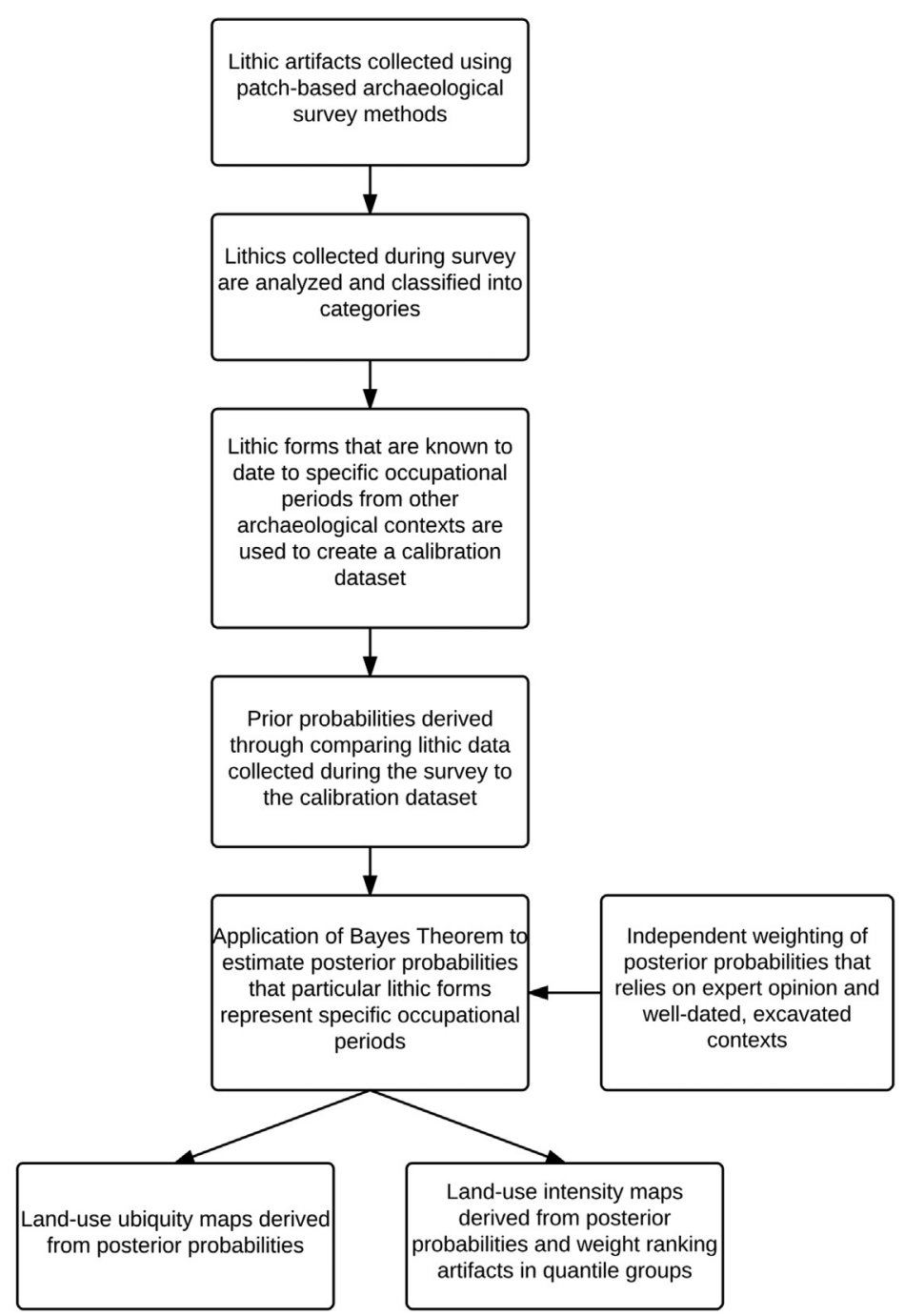

Fig. 4. Conceptual map of Bayesian methodology.

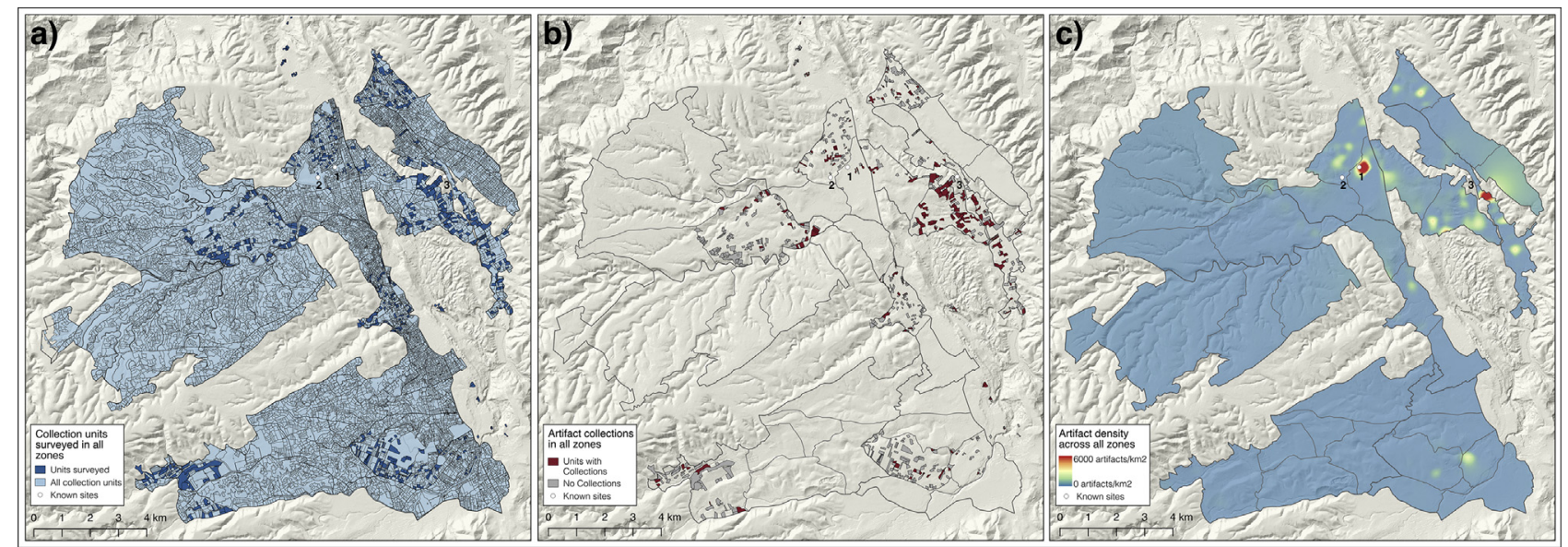

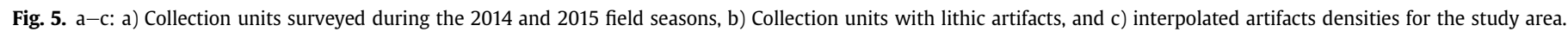
Previously recorded sites are labeled as 1. Las Fuentes, 2. Ereta del Pedregal, and 3. Covacha de la Bellota.

recovered from 62 of the 100 collection units surveyed, with a maximum of 58 lithics collected from a single parcel (Diez Castillo et al., 2016).

\subsubsection{Zone 5}

Zone 5 is located east of zone 4, and is composed of two sectors, 5-1 and 5-2, both of which were sampled. Both sectors encompass

Please cite this article in press as: Snitker, G., et al., Patch-based survey methods for studying prehistoric human land-use in agriculturally modified landscapes: A case study from the Canal de Navarrés, eastern Spain, Quaternary International (2018), https://doi.org/10.1016/ j.quaint.2018.01.034 
transitional areas between upland areas in Zone 6 and the adjacent valley bottom. Zone 5-1 is located at the southern end of the valley, near the confluence of el barranco del Matet and the Riu Bolbaite, and produced a high density of lithic artifacts. Lithics were recovered from 26 out of 57 collection units surveyed. Notably, 131 lithic artifacts (including retouched flakes and blades) were recovered from collection unit 5-1-100181. In stark contrast, very few lithics were collected in sector 5-2, located to the north of sector 5-1. Low densities of lithic artifacts were recorded in only 4 out of 29 collection units in this sector.

\subsubsection{Zone 6}

Zone 6 is located in an upland area within the municipality of Navarrés and is the only sector that drains north to the Riu Escalona, which joins the main Riu Xúquer upstream of Sumácarcer. In this zone, only sector 6-1 was sampled and surveyed, yielding lithics in 14 of 75 collection units (Diez Castillo et al., 2016). This area, along with sectors $2-2,3-3$, and $5-2$, has one of the lowest densities of artifacts in the Canal de Navarrés survey area.

\subsubsection{Zone 7}

Zone 7 is located in the upland area at the western most edge of the Canal de Navarrés survey area. Sector 7-4 is located on the border between Navarrés to the north and Bolbaite to the south and encompasses the watershed that drains to Las Fuentes (Playamonte) and the Riu Bolbaite. A total of 120 collection units were surveyed in sector 7-4 with lithic artifacts recovered from 22 fields.

\subsubsection{Zone 9}

Zone 9 is located within the municipality of Enguera and within a relatively high, upland area in the southern most portion of the survey area. Survey was concentrated in sector 9-6, located at the southeastern end of the Caroig massif, crossed by the Riajuelo rambla before it joins the Riu Sellent. Of the 40 collection units surveyed, artifacts were recovered from 21 fields, making this one of the more productive areas within the survey area. Most artifacts recovered in this zone are Iberian-Roman ceramics related to the nearby Iberian site of Cerro Lucena and are not included in the current analysis (Diez Castillo et al., 2016).

\subsubsection{Zone 10}

During the 2015 field season, additional parcels outside of the original survey zones were identified as areas that could potential yield more information regarding the spatial distribution of prehistoric land-use in the Canal de Navarrés (Fig. 5a). These parcels were primarily located in transitional areas outside of the main valley. A total of 52 additional collection units were identified for survey and labeled as zone 10 . A total of 17 of the 52 units surveyed contained lithic artifacts, including burins, retouched flakes, notches, and blades.

\subsection{Spatial distribution and density of artifacts in the Canal de Navarrés}

The spatial distribution of surveyed collection units in each zone, units where lithic artifacts were collected, and the density of artifacts across the survey area are illustrated in Fig. 5a-c. Artifact densities were calculated by dividing the frequency of lithic artifacts observed in each collection unit by its area $\left(\mathrm{km}^{2}\right)$. The resulting densities were interpolated using bilinear b-spine interpolation (directional steps $=150 \mathrm{~m}$; smoothing parameter $=0.01$; $30 \mathrm{~m}$ resolution) to create a continuous estimation of artifact density. All raster, vector, and interpolation calculations are conducted in GRASS GIS Version 7.0 (GRASS Development Team, 2016).

\subsection{Applying Bayesian age estimates to surface assemblages}

\subsubsection{Prior probabilities and collection unit weights}

Prior probabilities of each artifact form, calculated from the calibration dataset, are graphically illustrated in Fig. 6. Artifact forms present in only one ( $25.0 \%$ of forms), two ( $25.0 \%$ of forms), or three (18.8\% of forms) occupational periods are considered temporally sensitive indicators. These include burins, notches and denticulated flakes, Mousterian technology (bifaces and side scrapers), denticulated sickle blades, retouched blades, invasive retouched blades, microburins, backed blades, truncated blades, projectile points (foliate and other bifacial points), and discoidal/ levallois flake technology. Trapeze microliths and triangle microliths occur in four occupation periods and are considered less temporally sensitive.

Three artifact forms are present in over half $(\geq 5)$ of the occupational periods and are therefore general indicators of occupation. These include blade technology (blades, bladelets, and blade core preparation), end scrapers, and undifferentiated lithics (flakes, chunks, and shatter). Although the extended temporal range of these artifacts makes it difficult to identify the occupational period most closely associated with them, it does provide a means through which to identify the overall presence of prehistoric land-use. The weights applied the posterior probability of each occupation period for all collection units that contained artifacts (not including collection units with only undifferentiated lithics) are shown in Table 5. Collection units with only undifferentiated lithics were assigned equal weights ( $1 / \mathrm{n}$ occupational periods or 0.111$)$.

\subsubsection{Posterior probabilities and estimating the age of surface assemblages in the Canal de Navarrés}

Table 6 shows the posterior probabilities that material recovered from collection units are associated with each occupational period. Units in which only undifferentiated lithics were collected have equal posterior probabilities for each occupational period and are not shown. These results illustrate the extensive mixing of surface assemblages in the Canal de Navarrés survey area, with very few collection units possessing a distinct, unimodal association. It is important to note that posterior probabilities are an expression of both prior knowledge and an assessment of our confidence in assigning occupational periods to artifacts on the landscape. For this reason, the relative strength of the posterior probabilities is most important, not the absolute value of any given collection unit. For example, a collection unit associated with a single occupation period would have a posterior probability of 1 for that period and 0 for all other periods. Similarly, a collection unit with three associated occupational periods would have posterior probabilities of 0.333 for each of the represented periods and 0 for all other periods. Although the absolute values of the posterior probabilities in these two examples differ by a factor of 3 , they are of equal weight when assessing the likelihood of land-use during each occupational period.

\subsubsection{Land-use ubiquity in the Canal de Navarrés survey area}

Posterior probabilities of lithic material associated with each occupational period provide an in-depth perspective on variation in land-use through time within the survey area. But posterior probabilities alone do not give a sense of how land-use is distributed spatially in each occupational period. A simple method for evaluating both spatial and temporal dimensions is through a measure of land-use ubiquity (Barton et al., 2004) for each occupational period.

Land-use ubiquity is assessed by first extracting the locations of centroids from all collection units surveyed during the 2014 and 2015 field seasons. These spatial data are then merged with the posterior probabilities for each occupational period, while units 

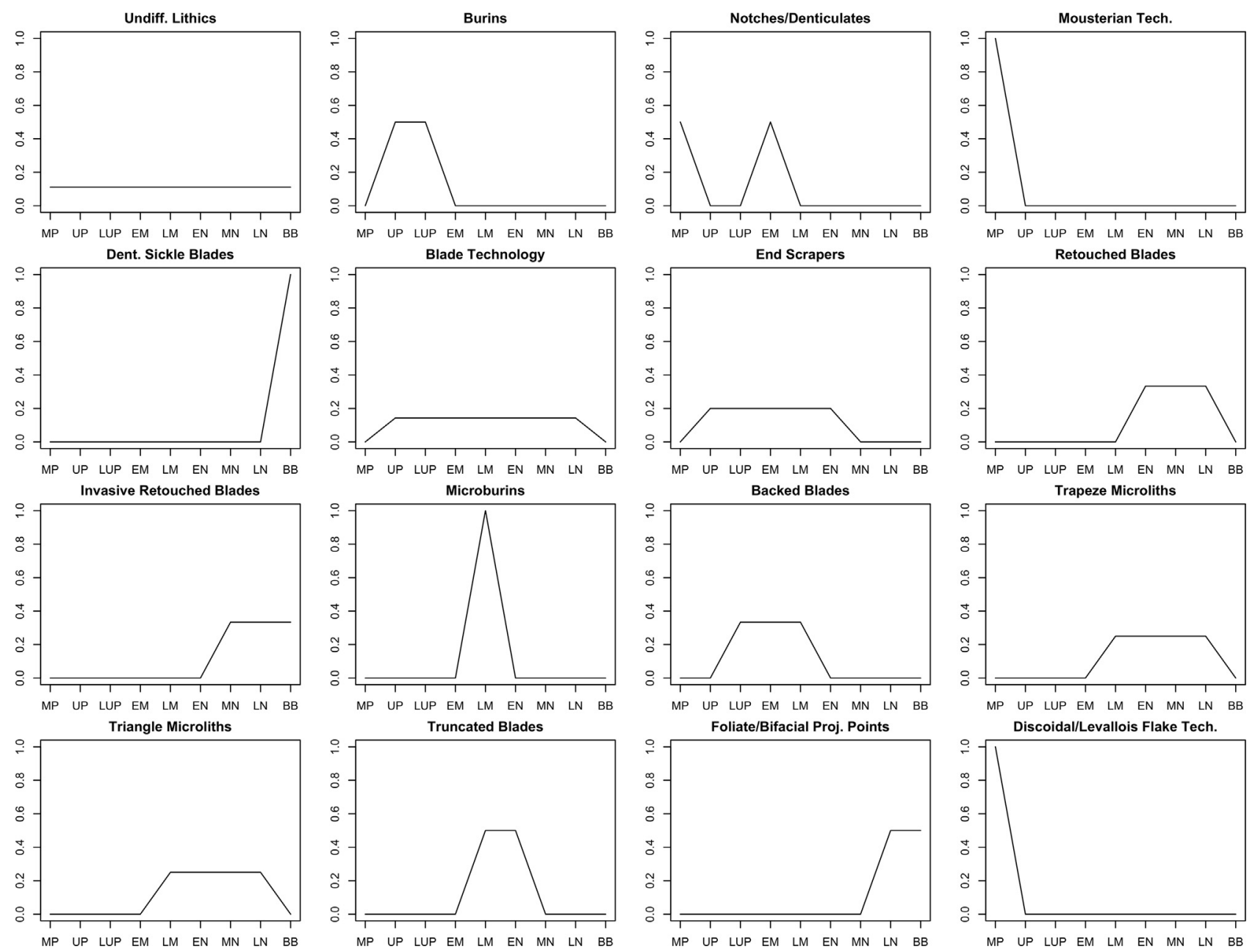

Fig. 6. Graphical representation of prior probabilities derived from the calibration dataset for the Canal de Navarrés.

with no observed artifacts are assigned probabilities of 0 . The resulting spatial points contain three dimensions: $x$ and $y$ locational information, and $\mathrm{z}$, the posterior probability that a given collection unit is associated with each occupational period. Using b-spline interpolation (directional steps $=150 \mathrm{~m}$; smoothing parameter $=0.01 ; 30 \mathrm{~m}$ resolution), a probability surface for each occupational period is created between all collection unit centroids at the scale of the entire survey area. Values are then rescaled from 0 to 1 to facilitate comparison between occupational periods. This method allows us to use the presence/absence of artifacts included in our original sample to estimate the posterior probability of each occupation period in additional areas. The resulting land-use ubiquity maps for each occupational period are shown in Fig. 7.

\subsubsection{Land-use intensity in the Canal de Navarrés survey area}

Land-use ubiquity alone does not account for the intensity of land-use through time. For example, a collection unit may contain only a single artifact that is uniquely associated with a single occupation period, while another collection unit has 100 artifacts uniquely associated with a single occupation period. Both of these collection units would be assigned a high posterior probability for the associated occupational period, even though the intensity of land-use in those two collection units is likely very different. Estimations of artifact abundance and accumulation rates are incorporated into land-use ubiquity to assess the overall land-use intensity (Barton et al., 1999, 2004) throughout the survey area.
Artifact abundances are weighted by ranking artifacts in each collection unit by artifact density (lithic pieces per square kilometer) into five quantile groups (Barton et al., 1999, 2004). Each group is assigned a weight, which is then multiplied by the posterior probabilities for that collection unit. Weights are as follows: 1.00 for collection units with densities in the 91st-100th percentile, 0.90 for collection units in the 75 th-90th percentile, 0.75 for collection units in the $51 \mathrm{st}-75$ th percentile, 0.50 for collection units in the 26th-50th percentile, 0.25 for collection units in the 1 st -25 th percentile, and 0 for collection units with no artifacts. The resulting index accounts for the density of artifacts in assessing the intensity of land-use across the study area. See Barton et al. (2004) for more details on this methodology.

Artifact accumulation rates through time can also influence the interpretation of land-use intensity for each occupation period. This is particularly relevant as the chronological sequence for the Canal de Navarrés contains highly variable accumulation times (e.g. Middle Paleolithic encompasses 70 millennia and Bell Beaker encompasses 0.7 millennia). The intensity index developed for artifact densities is scaled by the number of years in each occupational period (in kyr) to account for differences in artifact accumulation rates (Barton et al., 2004). All values are then rescaled from 0 to 1 and b-spline interpolation (directional steps $=150 \mathrm{~m}$; smoothing parameter $=0.01 ; 30 \mathrm{~m}$ resolution) is used to generate a settlement intensity surface at the scale of the survey area. The resulting landuse intensity maps for each occupational period are shown in Fig. 8. 
Table 5

Weights calculated for all collection units with artifacts other than undifferentiated lithics.

\begin{tabular}{|c|c|c|c|c|c|c|c|c|c|c|c|}
\hline Zone & Sector & Parcel & MP & UP & LUP & EM & LM & EN & $\mathrm{MN}$ & LN & $\mathrm{BB}$ \\
\hline \multirow[t]{5}{*}{1} & 1 & 900568 & 0.067 & 0.200 & 0.200 & 0.200 & 0.067 & 0.067 & 0.067 & 0.067 & 0.067 \\
\hline & & 1100119 & 0.063 & 0.188 & 0.188 & 0.188 & 0.125 & 0.063 & 0.063 & 0.063 & 0.063 \\
\hline & & 1100140 & 0.111 & 0.111 & 0.111 & 0.111 & 0.111 & 0.111 & 0.111 & 0.111 & 0.111 \\
\hline & & 1100168 & 0.111 & 0.111 & 0.111 & 0.111 & 0.111 & 0.111 & 0.111 & 0.111 & 0.111 \\
\hline & 2 & 1100355 & 0.053 & 0.158 & 0.158 & 0.158 & 0.158 & 0.105 & 0.053 & 0.105 & 0.053 \\
\hline \multirow[t]{4}{*}{2} & 2 & 600256 & 0.067 & 0.200 & 0.200 & 0.200 & 0.067 & 0.067 & 0.067 & 0.067 & 0.067 \\
\hline & & 900041 & 0.111 & 0.111 & 0.111 & 0.111 & 0.111 & 0.111 & 0.111 & 0.111 & 0.111 \\
\hline & 7 & 1300156 & 0.250 & 0.083 & 0.083 & 0.167 & 0.083 & 0.083 & 0.083 & 0.083 & 0.083 \\
\hline & & 400173 & 0.111 & 0.111 & 0.111 & 0.111 & 0.111 & 0.111 & 0.111 & 0.111 & 0.111 \\
\hline \multirow[t]{6}{*}{3} & 2 & 2100131 & 0.067 & 0.200 & 0.200 & 0.200 & 0.067 & 0.067 & 0.067 & 0.067 & 0.067 \\
\hline & 3 & 2200018 & 0.067 & 0.200 & 0.200 & 0.200 & 0.067 & 0.067 & 0.067 & 0.067 & 0.067 \\
\hline & & 2500013 & 0.067 & 0.067 & 0.067 & 0.067 & 0.067 & 0.067 & 0.067 & 0.267 & 0.267 \\
\hline & & 2200015 & 0.067 & 0.200 & 0.200 & 0.200 & 0.067 & 0.067 & 0.067 & 0.067 & 0.067 \\
\hline & & 2200016 & 0.273 & 0.091 & 0.091 & 0.091 & 0.091 & 0.091 & 0.091 & 0.091 & 0.091 \\
\hline & 5 & 1000050 & 0.067 & 0.200 & 0.200 & 0.200 & 0.067 & 0.067 & 0.067 & 0.067 & 0.067 \\
\hline \multirow[t]{28}{*}{4} & 1 & 200087 & 0.048 & 0.095 & 0.095 & 0.095 & 0.143 & 0.095 & 0.095 & 0.095 & 0.238 \\
\hline & & 100392 & 0.067 & 0.200 & 0.200 & 0.200 & 0.067 & 0.067 & 0.067 & 0.067 & 0.067 \\
\hline & & 100312 & 0.067 & 0.200 & 0.200 & 0.200 & 0.067 & 0.067 & 0.067 & 0.067 & 0.067 \\
\hline & & 100307 & 0.059 & 0.294 & 0.177 & 0.177 & 0.059 & 0.059 & 0.059 & 0.059 & 0.059 \\
\hline & & 100279 & 0.059 & 0.177 & 0.177 & 0.177 & 0.177 & 0.059 & 0.059 & 0.059 & 0.059 \\
\hline & & 100168 & 0.046 & 0.091 & 0.091 & 0.091 & 0.091 & 0.091 & 0.091 & 0.182 & 0.227 \\
\hline & & 0200089B & 0.067 & 0.200 & 0.200 & 0.200 & 0.067 & 0.067 & 0.067 & 0.067 & 0.067 \\
\hline & & 200073 & 0.059 & 0.118 & 0.118 & 0.118 & 0.059 & 0.177 & 0.177 & 0.118 & 0.059 \\
\hline & & 100276 & 0.188 & 0.125 & 0.125 & 0.250 & 0.063 & 0.063 & 0.063 & 0.063 & 0.063 \\
\hline & & 100283 & 0.056 & 0.222 & 0.167 & 0.167 & 0.167 & 0.056 & 0.056 & 0.056 & 0.056 \\
\hline & & 100277 & 0.071 & 0.143 & 0.214 & 0.214 & 0.071 & 0.071 & 0.071 & 0.071 & 0.071 \\
\hline & & 100319 & 0.059 & 0.118 & 0.118 & 0.118 & 0.059 & 0.177 & 0.177 & 0.118 & 0.059 \\
\hline & & 100164 & 0.059 & 0.118 & 0.118 & 0.118 & 0.059 & 0.177 & 0.177 & 0.118 & 0.059 \\
\hline & & 100137 & 0.067 & 0.200 & 0.200 & 0.200 & 0.067 & 0.067 & 0.067 & 0.067 & 0.067 \\
\hline & & 0100109B & 0.188 & 0.125 & 0.125 & 0.250 & 0.063 & 0.063 & 0.063 & 0.063 & 0.063 \\
\hline & & 0100109C & 0.063 & 0.125 & 0.125 & 0.125 & 0.063 & 0.063 & 0.063 & 0.063 & 0.313 \\
\hline & & 200076 & 0.067 & 0.200 & 0.200 & 0.200 & 0.067 & 0.067 & 0.067 & 0.067 & 0.067 \\
\hline & & 200074 & 0.067 & 0.200 & 0.200 & 0.200 & 0.067 & 0.067 & 0.067 & 0.067 & 0.067 \\
\hline & & 200086 & 0.273 & 0.091 & 0.091 & 0.091 & 0.091 & 0.091 & 0.091 & 0.091 & 0.091 \\
\hline & & 200075 & 0.067 & 0.200 & 0.200 & 0.200 & 0.067 & 0.067 & 0.067 & 0.067 & 0.067 \\
\hline & & 100221 & 0.214 & 0.071 & 0.071 & 0.286 & 0.071 & 0.071 & 0.071 & 0.071 & 0.071 \\
\hline & & 100252 & 0.067 & 0.200 & 0.200 & 0.200 & 0.067 & 0.067 & 0.067 & 0.067 & 0.067 \\
\hline & & 100245 & 0.067 & 0.200 & 0.200 & 0.200 & 0.067 & 0.067 & 0.067 & 0.067 & 0.067 \\
\hline & & 100353 & 0.067 & 0.200 & 0.200 & 0.200 & 0.067 & 0.067 & 0.067 & 0.067 & 0.067 \\
\hline & & 100147 & 0.067 & 0.200 & 0.200 & 0.200 & 0.067 & 0.067 & 0.067 & 0.067 & 0.067 \\
\hline & & 100155 & 0.273 & 0.091 & 0.091 & 0.091 & 0.091 & 0.091 & 0.091 & 0.091 & 0.091 \\
\hline & & 0100109A & 0.111 & 0.111 & 0.111 & 0.111 & 0.111 & 0.111 & 0.111 & 0.111 & 0.111 \\
\hline & 2 & 1000508 & 0.048 & 0.143 & 0.143 & 0.143 & 0.143 & 0.143 & 0.095 & 0.095 & 0.048 \\
\hline \multirow[t]{14}{*}{5} & 1 & 100181 & 0.074 & 0.222 & 0.222 & 0.222 & 0.111 & 0.037 & 0.037 & 0.037 & 0.037 \\
\hline & & 100288 & 0.059 & 0.177 & 0.177 & 0.177 & 0.177 & 0.059 & 0.059 & 0.059 & 0.059 \\
\hline & & 100372 & 0.040 & 0.200 & 0.120 & 0.120 & 0.120 & 0.120 & 0.120 & 0.120 & 0.040 \\
\hline & & 400003 & 0.046 & 0.136 & 0.136 & 0.136 & 0.046 & 0.046 & 0.046 & 0.227 & 0.182 \\
\hline & & 200018 & 0.048 & 0.143 & 0.095 & 0.095 & 0.095 & 0.048 & 0.048 & 0.238 & 0.191 \\
\hline & & 100263 & 0.071 & 0.214 & 0.214 & 0.143 & 0.071 & 0.071 & 0.071 & 0.071 & 0.071 \\
\hline & & 100292 & 0.125 & 0.125 & 0.125 & 0.313 & 0.063 & 0.063 & 0.063 & 0.063 & 0.063 \\
\hline & & 400004 & 0.067 & 0.200 & 0.200 & 0.200 & 0.067 & 0.067 & 0.067 & 0.067 & 0.067 \\
\hline & & 200012 & 0.077 & 0.077 & 0.077 & 0.077 & 0.077 & 0.077 & 0.077 & 0.077 & 0.385 \\
\hline & & 300018 & 0.067 & 0.200 & 0.200 & 0.200 & 0.067 & 0.067 & 0.067 & 0.067 & 0.067 \\
\hline & & 100180 & 0.067 & 0.200 & 0.200 & 0.200 & 0.067 & 0.067 & 0.067 & 0.067 & 0.067 \\
\hline & & 100199 & 0.067 & 0.200 & 0.200 & 0.200 & 0.067 & 0.067 & 0.067 & 0.067 & 0.067 \\
\hline & & 500045 & 0.077 & 0.077 & 0.077 & 0.077 & 0.077 & 0.077 & 0.077 & 0.077 & 0.385 \\
\hline & 2 & 100028 & 0.067 & 0.200 & 0.200 & 0.200 & 0.067 & 0.067 & 0.067 & 0.067 & 0.067 \\
\hline \multirow[t]{3}{*}{6} & 1 & 300362 & 0.063 & 0.125 & 0.125 & 0.125 & 0.063 & 0.063 & 0.063 & 0.063 & 0.313 \\
\hline & & 300361 & 0.063 & 0.125 & 0.188 & 0.188 & 0.188 & 0.063 & 0.063 & 0.063 & 0.063 \\
\hline & & 300204 & 0.067 & 0.200 & 0.200 & 0.200 & 0.067 & 0.067 & 0.067 & 0.067 & 0.067 \\
\hline \multirow[t]{4}{*}{7} & 4 & 1300198 & 0.071 & 0.071 & 0.214 & 0.214 & 0.143 & 0.071 & 0.071 & 0.071 & 0.071 \\
\hline & & 500313 & 0.056 & 0.167 & 0.167 & 0.167 & 0.056 & 0.056 & 0.056 & 0.167 & 0.111 \\
\hline & & 500317 & 0.067 & 0.200 & 0.200 & 0.200 & 0.067 & 0.067 & 0.067 & 0.067 & 0.067 \\
\hline & & 1300166 & 0.067 & 0.200 & 0.200 & 0.200 & 0.067 & 0.067 & 0.067 & 0.067 & 0.067 \\
\hline
\end{tabular}

\section{Discussion}

\subsection{Artifact densities and spatial distribution}

Our off-site survey methodology, adapted for surveying in agriculturally modified landscapes, resulted in a spatially and temporally explicit evaluation of prehistoric land-use in the Canal de Navarrés. Artifact densities demonstrated spatial variation throughout the study area, with zones 1, 2, 4 and 5 yielding highest concentrations of artifacts. Upland areas in zones 3, 6, 7, 8, and 9, have relatively low concentrations of lithic artifacts. This distribution suggests that lowland and transitional areas were preferentially used for prehistoric land-use activities resulting in relatively high artifact accumulations (i.e. encampments, resources 
Table 6

Posterior probabilities for all collection units with artifacts other than undifferentiated lithics.

\begin{tabular}{|c|c|c|c|c|c|c|c|c|c|c|c|}
\hline Zone & Sector & Parcel & MP & UP & LUP & EM & LM & EN & MN & $\mathrm{LN}$ & $\mathrm{BB}$ \\
\hline \multirow[t]{5}{*}{1} & 1 & 900568 & 0.036 & 0.214 & 0.214 & 0.214 & 0.071 & 0.071 & 0.071 & 0.071 & 0.036 \\
\hline & & 1100119 & 0.033 & 0.200 & 0.200 & 0.200 & 0.133 & 0.067 & 0.067 & 0.067 & 0.033 \\
\hline & & 1100140 & 0.182 & 0.091 & 0.091 & 0.182 & 0.091 & 0.091 & 0.091 & 0.091 & 0.091 \\
\hline & & 1100168 & 0.063 & 0.125 & 0.125 & 0.125 & 0.125 & 0.125 & 0.125 & 0.125 & 0.063 \\
\hline & 2 & 1100355 & 0.024 & 0.146 & 0.146 & 0.146 & 0.220 & 0.146 & 0.049 & 0.098 & 0.024 \\
\hline \multirow[t]{4}{*}{2} & 2 & 600256 & 0.036 & 0.214 & 0.214 & 0.214 & 0.071 & 0.071 & 0.071 & 0.071 & 0.036 \\
\hline & & 900041 & 0.200 & 0.100 & 0.100 & 0.100 & 0.100 & 0.100 & 0.100 & 0.100 & 0.100 \\
\hline & 7 & 1300156 & 0.353 & 0.059 & 0.059 & 0.235 & 0.059 & 0.059 & 0.059 & 0.059 & 0.059 \\
\hline & & 400173 & 0.077 & 0.077 & 0.077 & 0.077 & 0.154 & 0.154 & 0.154 & 0.154 & 0.077 \\
\hline \multirow[t]{6}{*}{3} & 2 & 2100131 & 0.036 & 0.214 & 0.214 & 0.214 & 0.071 & 0.071 & 0.071 & 0.071 & 0.036 \\
\hline & 3 & 2200018 & 0.036 & 0.214 & 0.214 & 0.214 & 0.071 & 0.071 & 0.071 & 0.071 & 0.036 \\
\hline & & 2500013 & 0.043 & 0.043 & 0.043 & 0.043 & 0.043 & 0.043 & 0.043 & 0.348 & 0.348 \\
\hline & & 2200015 & 0.036 & 0.214 & 0.214 & 0.214 & 0.071 & 0.071 & 0.071 & 0.071 & 0.036 \\
\hline & & 2200016 & 0.429 & 0.071 & 0.071 & 0.071 & 0.071 & 0.071 & 0.071 & 0.071 & 0.071 \\
\hline & 5 & 1000050 & 0.036 & 0.214 & 0.214 & 0.214 & 0.071 & 0.071 & 0.071 & 0.071 & 0.036 \\
\hline \multirow[t]{28}{*}{4} & 1 & 200087 & 0.020 & 0.080 & 0.080 & 0.080 & 0.180 & 0.120 & 0.120 & 0.120 & 0.200 \\
\hline & & 100392 & 0.036 & 0.214 & 0.214 & 0.214 & 0.071 & 0.071 & 0.071 & 0.071 & 0.036 \\
\hline & & 100312 & 0.036 & 0.214 & 0.214 & 0.214 & 0.071 & 0.071 & 0.071 & 0.071 & 0.036 \\
\hline & & 100307 & 0.045 & 0.341 & 0.205 & 0.205 & 0.045 & 0.045 & 0.045 & 0.045 & 0.023 \\
\hline & & 100279 & 0.029 & 0.171 & 0.171 & 0.171 & 0.257 & 0.057 & 0.057 & 0.057 & 0.029 \\
\hline & & 100168 & 0.019 & 0.077 & 0.077 & 0.077 & 0.077 & 0.077 & 0.077 & 0.231 & 0.289 \\
\hline & & 0200089B & 0.036 & 0.214 & 0.214 & 0.214 & 0.071 & 0.071 & 0.071 & 0.071 & 0.036 \\
\hline & & 200073 & 0.025 & 0.100 & 0.100 & 0.100 & 0.050 & 0.225 & 0.225 & 0.150 & 0.025 \\
\hline & & 100276 & 0.171 & 0.114 & 0.114 & 0.343 & 0.057 & 0.057 & 0.057 & 0.057 & 0.029 \\
\hline & & 100283 & 0.021 & 0.250 & 0.187 & 0.187 & 0.187 & 0.063 & 0.042 & 0.042 & 0.021 \\
\hline & & 100277 & 0.030 & 0.121 & 0.273 & 0.273 & 0.091 & 0.061 & 0.061 & 0.061 & 0.030 \\
\hline & & 100319 & 0.025 & 0.100 & 0.100 & 0.100 & 0.050 & 0.225 & 0.225 & 0.150 & 0.025 \\
\hline & & 100164 & 0.025 & 0.100 & 0.100 & 0.100 & 0.050 & 0.225 & 0.225 & 0.150 & 0.025 \\
\hline & & 100137 & 0.036 & 0.214 & 0.214 & 0.214 & 0.071 & 0.071 & 0.071 & 0.071 & 0.036 \\
\hline & & 0100109B & 0.171 & 0.114 & 0.114 & 0.343 & 0.057 & 0.057 & 0.057 & 0.057 & 0.029 \\
\hline & & 0100109C & 0.032 & 0.129 & 0.129 & 0.129 & 0.065 & 0.065 & 0.065 & 0.065 & 0.323 \\
\hline & & 200076 & 0.036 & 0.214 & 0.214 & 0.214 & 0.071 & 0.071 & 0.071 & 0.071 & 0.036 \\
\hline & & 200074 & 0.036 & 0.214 & 0.214 & 0.214 & 0.071 & 0.071 & 0.071 & 0.071 & 0.036 \\
\hline & & 200086 & 0.429 & 0.071 & 0.071 & 0.071 & 0.071 & 0.071 & 0.071 & 0.071 & 0.071 \\
\hline & & 200075 & 0.036 & 0.214 & 0.214 & 0.214 & 0.071 & 0.071 & 0.071 & 0.071 & 0.036 \\
\hline & & 100221 & 0.286 & 0.048 & 0.048 & 0.381 & 0.048 & 0.048 & 0.048 & 0.048 & 0.048 \\
\hline & & 100252 & 0.036 & 0.214 & 0.214 & 0.214 & 0.071 & 0.071 & 0.071 & 0.071 & 0.036 \\
\hline & & 100245 & 0.036 & 0.214 & 0.214 & 0.214 & 0.071 & 0.071 & 0.071 & 0.071 & 0.036 \\
\hline & & 100353 & 0.036 & 0.214 & 0.214 & 0.214 & 0.071 & 0.071 & 0.071 & 0.071 & 0.036 \\
\hline & & 100147 & 0.036 & 0.214 & 0.214 & 0.214 & 0.071 & 0.071 & 0.071 & 0.071 & 0.036 \\
\hline & & 100155 & 0.429 & 0.071 & 0.071 & 0.071 & 0.071 & 0.071 & 0.071 & 0.071 & 0.071 \\
\hline & & 0100109A & 0.200 & 0.100 & 0.100 & 0.100 & 0.100 & 0.100 & 0.100 & 0.100 & 0.100 \\
\hline & 2 & 1000508 & 0.022 & 0.130 & 0.130 & 0.130 & 0.196 & 0.196 & 0.087 & 0.087 & 0.022 \\
\hline \multirow[t]{14}{*}{5} & 1 & 100181 & 0.055 & 0.218 & 0.273 & 0.273 & 0.109 & 0.027 & 0.018 & 0.018 & 0.009 \\
\hline & & 100288 & 0.020 & 0.184 & 0.184 & 0.184 & 0.245 & 0.082 & 0.041 & 0.041 & 0.020 \\
\hline & & 100372 & 0.014 & 0.203 & 0.122 & 0.122 & 0.122 & 0.162 & 0.122 & 0.122 & 0.014 \\
\hline & & 400003 & 0.021 & 0.125 & 0.125 & 0.125 & 0.042 & 0.042 & 0.042 & 0.312 & 0.167 \\
\hline & & 200018 & 0.022 & 0.130 & 0.087 & 0.087 & 0.087 & 0.043 & 0.043 & 0.326 & 0.174 \\
\hline & & 100263 & 0.069 & 0.207 & 0.207 & 0.207 & 0.069 & 0.069 & 0.069 & 0.069 & 0.034 \\
\hline & & 100292 & 0.118 & 0.118 & 0.118 & 0.441 & 0.059 & 0.059 & 0.029 & 0.029 & 0.029 \\
\hline & & 400004 & 0.063 & 0.187 & 0.187 & 0.281 & 0.063 & 0.063 & 0.063 & 0.063 & 0.031 \\
\hline & & 200012 & 0.056 & 0.056 & 0.056 & 0.056 & 0.056 & 0.056 & 0.056 & 0.056 & 0.556 \\
\hline & & 300018 & 0.036 & 0.214 & 0.214 & 0.214 & 0.071 & 0.071 & 0.071 & 0.071 & 0.036 \\
\hline & & 100180 & 0.036 & 0.214 & 0.214 & 0.214 & 0.071 & 0.071 & 0.071 & 0.071 & 0.036 \\
\hline & & 100199 & 0.036 & 0.214 & 0.214 & 0.214 & 0.071 & 0.071 & 0.071 & 0.071 & 0.036 \\
\hline & & 500045 & 0.056 & 0.056 & 0.056 & 0.056 & 0.056 & 0.056 & 0.056 & 0.056 & 0.556 \\
\hline & 2 & 100028 & 0.036 & 0.214 & 0.214 & 0.214 & 0.071 & 0.071 & 0.071 & 0.071 & 0.036 \\
\hline \multirow[t]{3}{*}{6} & 1 & 300362 & 0.059 & 0.118 & 0.118 & 0.176 & 0.059 & 0.059 & 0.059 & 0.059 & 0.294 \\
\hline & & 300361 & 0.026 & 0.103 & 0.231 & 0.231 & 0.231 & 0.051 & 0.051 & 0.051 & 0.026 \\
\hline & & 300204 & 0.036 & 0.214 & 0.214 & 0.214 & 0.071 & 0.071 & 0.071 & 0.071 & 0.036 \\
\hline \multirow[t]{4}{*}{7} & 4 & 1300198 & 0.029 & 0.059 & 0.265 & 0.265 & 0.177 & 0.059 & 0.059 & 0.059 & 0.029 \\
\hline & & 500313 & 0.026 & 0.154 & 0.154 & 0.154 & 0.051 & 0.051 & 0.077 & 0.231 & 0.103 \\
\hline & & 500317 & 0.036 & 0.214 & 0.214 & 0.214 & 0.071 & 0.071 & 0.071 & 0.071 & 0.036 \\
\hline & & 1300166 & 0.036 & 0.214 & 0.214 & 0.214 & 0.071 & 0.071 & 0.071 & 0.071 & 0.036 \\
\hline
\end{tabular}

processing, villages, small-scale agricultural activities, etc.).

These results fit well with previous local and regional archaeological research, which has identified late Pleistocene and the Holocene occupations in and around lakes or upwellings in valley bottoms (Barton et al., 2010, 2012). Concentrations of lithic artifacts correspond with the previously known prehistoric sites, such as Ereta del Pedregal, Las Fuentes, and l'Albufera d'Anna. Several previously uninvestigated areas, such as the northern portion of sector 5-1 almost the entirety of sector $4-1$, and several collection units in Zone 10 near the small lake of Gorgo del Catalan, contain high densities of lithic artifacts and likely represent unrecorded prehistoric occupational areas.

Upland areas demonstrating low densities of artifacts also fit with our expectations regarding the distribution of prehistoric 

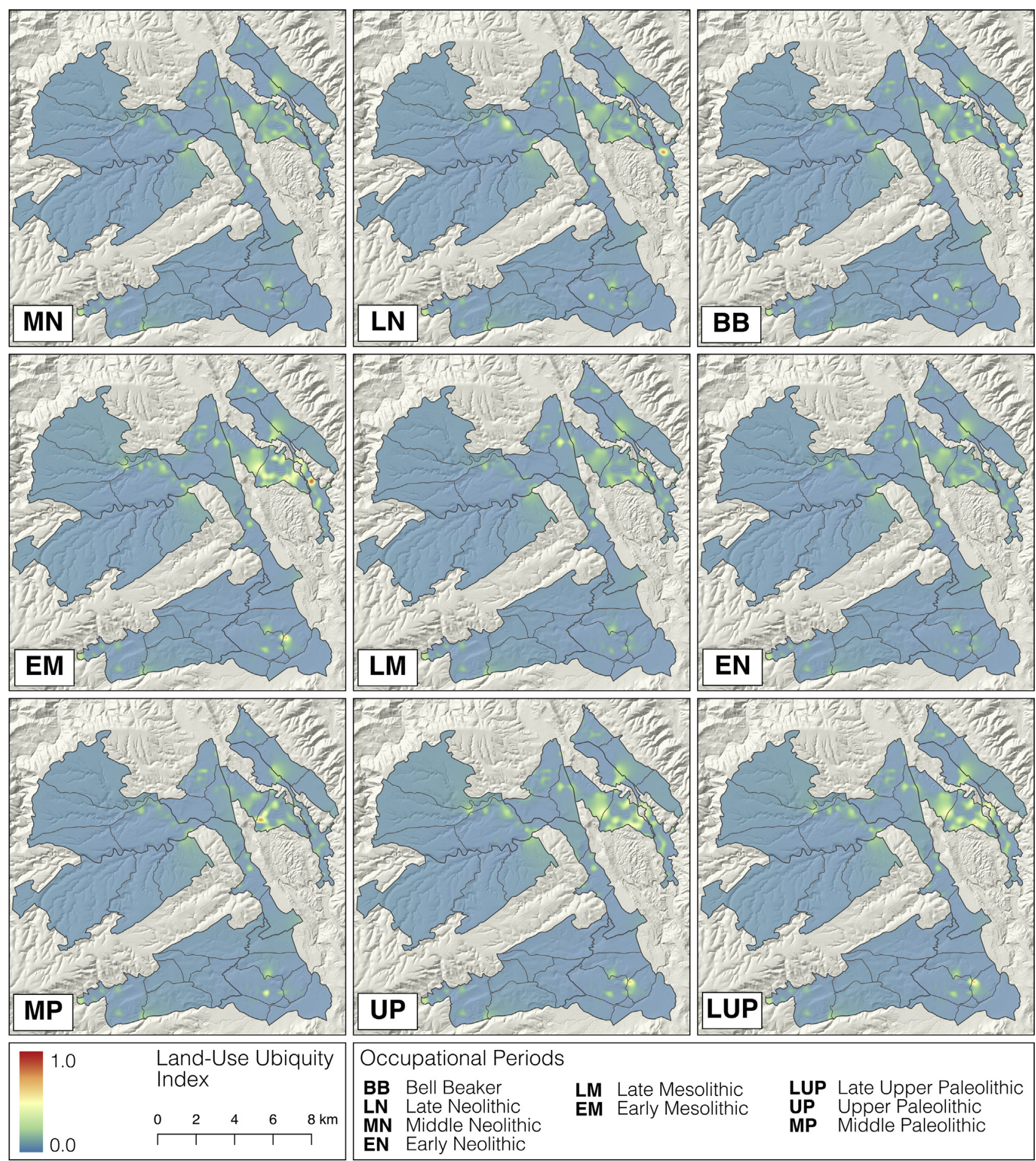

EM Early Mesolithic

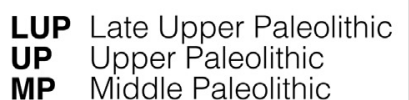

Fig. 7. B-spline interpolated surface (spline step $=150 \mathrm{~m}$, smoothing parameter $=0.01$ ) of land-use ubiquity by occupational period.

land-use in the survey area. These areas were likely less important for prehistoric land-use or were used for hunting or pastoralism, activities that may result in low-density artifact accumulations. It should be noted that erosion in upland areas and on hillslopes might have also contributed to low artifact densities. Portions of zones 3 and 9 are severely deflated with exposed bedrock between cultivated pockets of sediment. If surface artifact assemblages existed in these areas, they were likely re-deposited on the surface downslope.
To accommodate for the potential of redistributed artifacts due to erosion, we sampled upland fields with both highly deflated fields and fields with relatively stable, intact sediments. Both contexts yielded few prehistoric artifacts. Additionally, if artifacts were moving downslope due to sheetwash or other erosional processes, we would expect to find high concentrations of artifacts in terraces located at mid-slope or at the bases of hills. Even if artifacts were buried, repetitive plowing would have exposed some re-deposited artifacts in this zone. This is not the case, as the highest densities of 

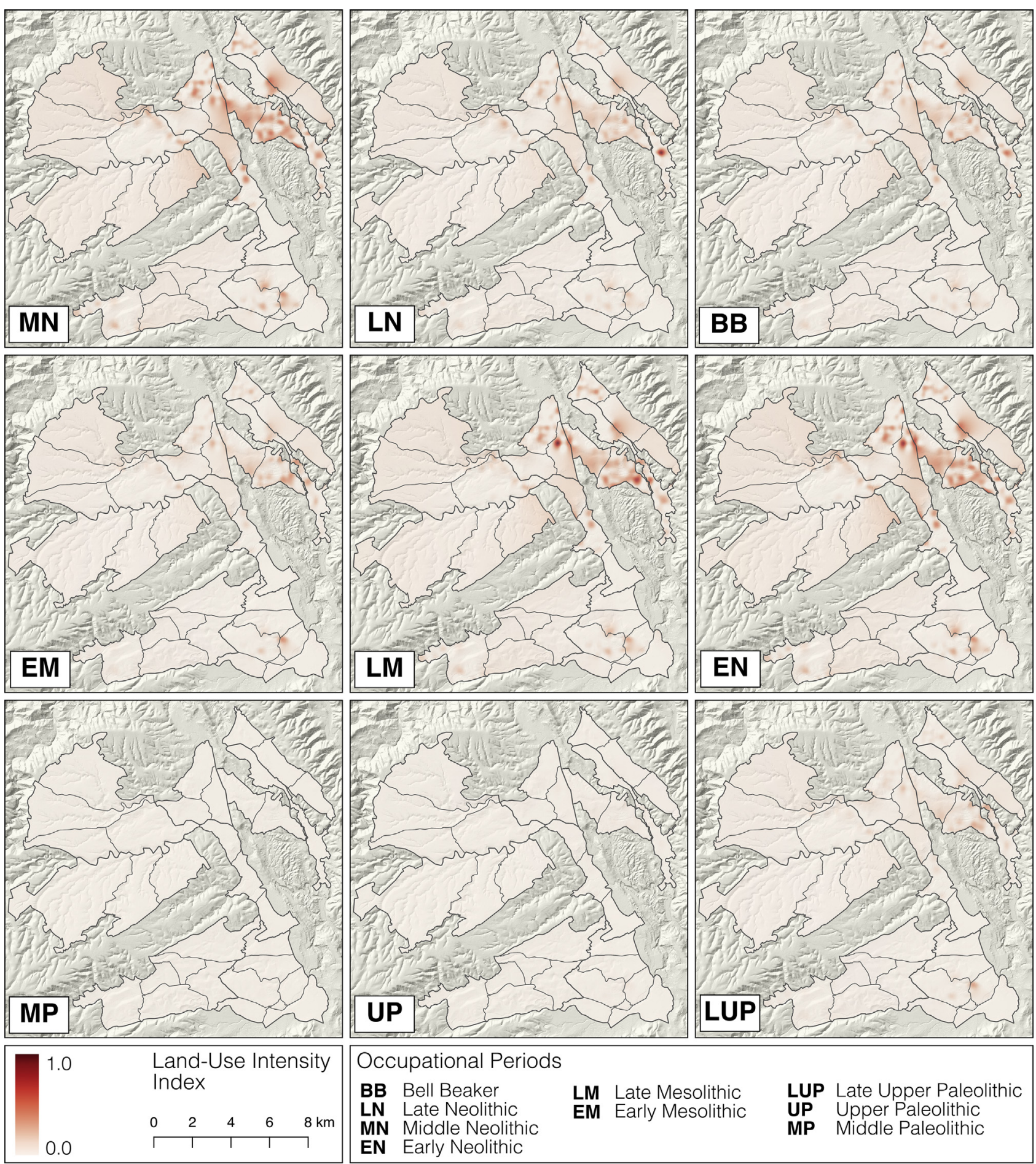

Occupational Periods

BB Bell Beaker

LN Late Neolithic

MN Middle Neolithic

EN Early Neolithic
LM Late Mesolithic

EM Early Mesolithic
LUP Late Upper Paleolithic

UP Upper Paleolithic

MP Middle Paleolithic

Fig. 8. B-spline interpolated surface (spline step $=150 \mathrm{~m}$, smoothing parameter $=0.01$ ) of land-use intensity by occupational period.

artifacts are found near perennial, mid-valley seeps and springs. We are confident that fields surveyed in zones 3, 6, 8, and 9 adequately represent low-density artifact accumulations and evidence for low-intensity upland prehistoric land-use.

\subsection{Paleolithic and Early Mesolithic land-use in the Canal de Navarrés}

Late Pleistocene and Early Holocene occupational periods (including the Middle Paleolithic, Upper Paleolithic, Late Upper
Paleolithic, and Early Mesolithic periods) shared similar spatial ubiquities and intensities throughout survey area with particular abundance in zones $3,4,5,6$, and 8 . Boxplots of posterior probabilities for lithics recovered from all collection units (Fig. 9) indicate high average posterior probabilities for Upper Paleolithic, Late Upper Paleolithic periods and Early Mesolithic, as well as abundant, high value outliers for the Middle Paleolithic. The statistical distribution of posterior probabilities for the Middle Paleolithic is explained by a combination of two artifact types with unimodal associations with this period (Mousterian technology and 


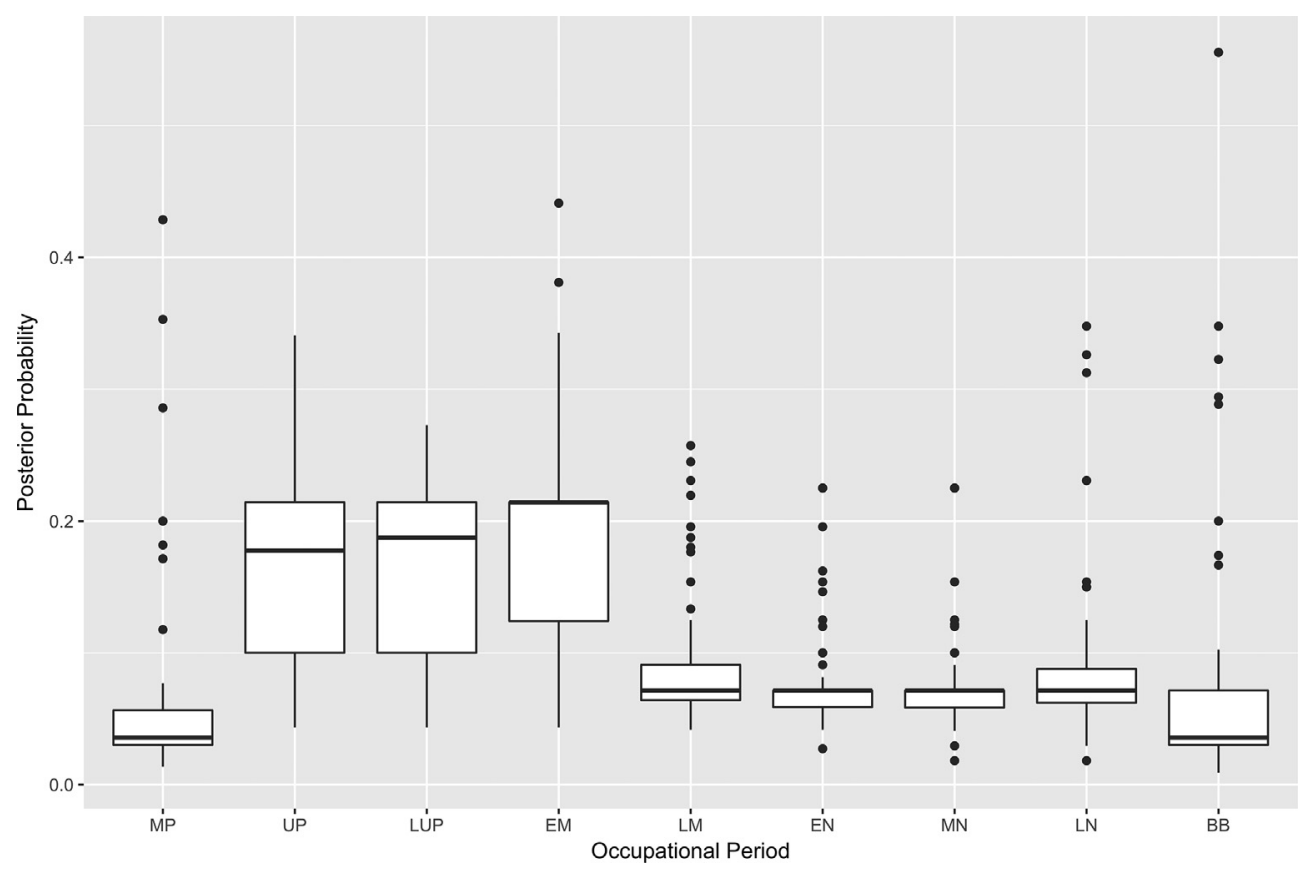

Fig. 9. Boxplots of posterior probabilities for lithics recovered from all collection units.

discoidal/levallois flake technology) and their presence in collection units where only these artifacts are observed. These two factors result in very high posterior probabilities and ubiquity values in spatially precise places on the landscape. Such is the case in sector 4-1, where Middle Paleolithic associated artifacts have high ubiquity values due to their presence in a small number collection units.

Upper Paleolithic, Late Upper Paleolithic, and early Mesolithic periods have the highest average ubiquity values and are widely distributed through the survey area. Ubiquity values indicate that these lithic forms are consistently located either near the previously identified prehistoric sites of Las Fuentes and l'Albufera d'Anna, as well as in the newly identified high-artifact density areas in sectors 4-1 and 5-1. The spatial distributions of these two periods are very similar and cannot be easily differentiated with the data collected.

Although ubiquity values during the late Pleistocene and early Holocene periods are relatively high, accumulation rates are very low due to the extended length of these periods (Table 3). As illustrated in Fig. 8, settlement intensity during the Paleolithic and early Mesolithic is consequently low when compared to the middle Holocene. Paleolithic land-use in the Canal de Navarrés was either at a consistent low-intensity, or episodic, with periods of highintensity followed by extended hiatuses.

\subsection{Late Mesolithic and Early-Middle Neolithic land-use in the Canal de Navarrés}

Undifferentiated lithics and blade technology represent the majority of the artifact forms associated with middle Holocene periods. The overall pattern of ubiquity and intensity follows closely with the general distribution of artifact densities across the study area, with concentrations of artifacts in lowland areas and near previously recorded sites. This is not to say that prehistoric land-use did not occurring during these periods, but rather we cannot confidently identify specific markers of Late Mesolithic or Neolithic occupations from the surface assemblages. Due to the short duration of each of these occupational periods, potential settlement intensity is relatively high across each of these periods.

It should be noted that it is during these periods that previous paleoecological research within the Canal de Navarrés identified substantial transition from pine to oak-dominated vegetation communities during the middle Holocene. Carrion and Van Geel (1999) remarked that this shift was independent of regional climate variation and co-occurred with an increase in regional charcoal concentrations associated with the arrival of early Neolithic. The lack of surface artifacts highly associated with the late Mesolithic and early-middle Neolithic occupational periods complicates this assertion. Further investigations into the social and ecological processes behind the co-occurrence of anthropogenic fire and this vegetation transition are needed.

\subsection{Late Neolithic and Bell Beaker (Chalcolithic) land-use in the Canal de Navarrés}

Estimates for the Late Neolithic and Bell Beaker land-use ubiquity and intensity maintain much of the same spatial structure as previous middle Holocene occupational periods. The pattern deviates in zones 4,5 , and 7 where lithic forms particularly associated with the Late Neolithic or Bell Beaker periods (denticulated sickle blades and foliate/bifacial projectile points) are present along with undifferentiated lithics. These areas are represented as 'hot-spots' of late prehistoric land-use (Fig. 7). Average posterior probabilities for the Late Neolithic and Bell Beaker periods are low, with the exception of a series of high value outliers caused by these artifact forms.

Although surface assemblages associated with Late Neolithic and Bell Beaker occupations do occur in same sector as the site of Ereta del Pedregal, it is notable that no high probability 'hot-spots' are located adjacent to the site. Potentially high rates of late Holocene erosion and deposition may have resulted in deeply buried assemblages that are not well represented on the surface. Late Neolithic and Chalcolithic artifacts were recovered at depths of over $2 \mathrm{~m}$ during previous excavations-well outside the plow zone and influence of most agricultural land-use (Fletcher Valls et al., 1964; Pla Ballester et al., 1983). Ereta del Pedregal is positioned within 
the valley bottom in a location susceptible to high rates of deposition from nearby drainages and active alluvial fans. Subsurface testing planned for the future field seasons will hopefully confirm that additional buried deposits closely associated with the Late Neolithic and Early Bell beaker periods are present.

\subsection{Future directions for evaluating archaeological surface assemblages in agricultural modified landscapes}

While the Bayesian approach applied to the Canal de Navarrés survey allows us to make interpretations about the changing spatial patterns and intensity of land-use through time, we believe future work can continue to improve these methods. One of the primary drivers of our results is the diversity of temporally sensitive lithic artifact forms assigned to each occupational period. Although only lithic artifacts were included in this project due to their abundance on the surface in the Canal de Navarrés, we could increase the diversity of temporally sensitive artifact forms by incorporating ceramic or groundstone artifacts (Fernández-López de Pablo and Barton, 2013). Since very few non-lithic artifacts we recovered in the Canal de Navarrés, increasing survey coverage or extending the bounds of the survey area to include surrounding valleys could result in a more diverse selection of artifact forms to create the calibration dataset for this analysis, as well as increase the spatial representativeness of our sample.

Additionally, the extensive modification of the survey area by modern agriculture played a critical role in the design of our survey methods, application of Bayesian methods, and the interpretation of the complex palimpsests of archaeological material in the Canal de Navarrés. Plowing, terrace building, and other ground disturbing agricultural activities provided a mechanism for moving artifacts from multiple occupational periods to the surface. We sampled zones with differing intensities of modern land-use in an effort to evaluate its effects on our survey results (see Table 1). Zones with high or moderate intensities of land-use yielded the highest densities of artifacts, but future work is required to determine to what degree these results are due to modern agriculture, patterns of prehistoric settlement, or both.

\section{Conclusions}

This paper presents the results of off-site, patch-based survey methods for agricultural modified landscapes in the Canal de Navarrés, Valencia, Spain. Digital data collection and a focus on evaluating artifact densities across the landscape allowed us to move away from attempting to identify sites and instead focus on recording spatial information pertaining to the prehistoric and modern land-use. This approach allows us to interpret the distribution and intensity of prehistoric artifacts, as well as evaluate the impact of modern agriculture, surface visibility, and geomorphic processes on our interpretations.

Bayesian methods for estimating ages of surface assemblages allow us to derive more robust chronologies from our data than would be otherwise possible. By formalizing how we incorporate prior knowledge about archaeological assemblages from throughout the Valencian region into our survey results, we can begin to address the interpretive problems associated with palimpsests. Combining Bayesian posterior probabilities, with GIS spatial analysis techniques, allows us to track diachronic change in the Canal de Navarrés through measurements of land-use ubiquity and intensity. These two measures provide a more complete picture of changing land-use that incorporates the influence of artifact density and accumulation rates through time. We are able to evaluate the chronology and intensity of prehistoric land-use with the goal of identifying changing interactions between long-term social and ecological systems. This work would not be possible without a suite of analytical tools that can accommodate intensively modified landscape and derive conclusions without relying on site-based investigations.

\section{Acknowledgements}

We thank Sean Bergin, Wendy Cegielski, Nari Miller, Pilar Escriba Ruiz, Carlos Navarro Luzón, and Isaac Sarrión Abad for their participation in the fieldwork and digital data collection during the Canal de Navarrés survey. This work is part of the MedLanD project, which is supported by a grant from the US National Science Foundation, Coupled Natural and Human Systems Program, Grant \#DEB-131372. This research was also funded by the Spanish Ministry of Economy, Industry and Competitiveness grants HAR201568962: EVOLPAST: Dinámicas evolutivas y patrones de variabilidad cultural de los últimos caza-recolectores y el primer neolítico en el este peninsular (circa $7000-4500$ cal BC). SPG is supported by University of Valencia (subprograma Atracció de Talent - Contractes Postdoctorals).

\section{References}

Aparicio Perez, J., 1973. Los yacimientos prehistoricos de la Albufera de Anna (Valencia). In: XIII Congreso Nacional de Arqueologia. Zaragoza, pp. 191-198. Aparicio Perez, J. 1979. El Mesolítico en Valencia y en el Mediterraneo occidental. Servico de Investigacion Prehistorica. Diputacion Provincial de Valencia, Valencia, Spain.

Aparicio Perez, J., 1981. Primeras dataciones de C14 para el Musteriense Valenciano. Archivo de Prehistoria Levantina XVI 9-38.

Arikan, B., 2012. Don't abhor your neighbor for he is a pastoralist: the GIS-based modeling of the past human-environment interactions and landscape changes in the Wadi el-Hasa, west-central Jordan. J. Archaeol. Sci. 39, 2908-2920. https://doi.org/10.1016/j.jas.2012.04.051.

Barton, C., Bernabeu, J., Aura, J., Garcia, O., 1999. Land-use dynamics and socioeconomic change: an example from the polop alto valley. Am. Antiq. 64, 609-634.

Barton, C.M., 1988. Lithic Variability and Middle Paleolithic Behavior : New Evidence from the Iberian Peninsula. In: British Archaeological Reports - International Series ; 408. British Archaeological Reports, Oxford.

Barton, C.M., Bernabeu, J., Aura, J.E., Garcia, O., La Roca, N., 2002. Dynamic landscapes, artifact taphonomy, and landuse modeling in the western mediterranean. Geoarchaeology 17, 155-190.

Barton, C.M., Bernabeu, J., Aura, J.E., Garcia, O., Schmich, S., Molina, L., 2004. Longterm socioecology and contingent landscapes. J. Archaeol. Meth. Theor 11, 253-295. https://doi.org/10.1023/B: JARM.0000047315.57162.b7.

Barton, C.M., Ullah, I., Bergin, S., 2010. Land-use, water and mediterranean landscapes: modeling long-term dynamics of complex socioecological systems. Proceedings of the Royal Society A 368, 5275-5297.

Barton, C.M., Ullah, I.I.T., Bergin, S.M., Mitasova, H., Sarjoughian, H., 2012. Looking for the future in the past: long-term change in socioecological systems. Ecol. Model. 241, 42-53. https://doi.org/10.1016/j.ecolmodel.2012.02.010.

Bernabeu Auban, J., 1999. Pots, symbols and territories: the archaeological context of neolithisation in mediterranean Spain. Documenta Praehistoria 26, 101-118.

Bernabeu Auban, J., Badal Garcia, E., 1992. A view of the vegetation and economic exploitation of the forest in the late neolithic sites of Les Jovades and Niuet (Alicante, Spain). Bull. Soc. Bot. Fr. 139, 697-714.

Bernabeu Auban, J., Perez Ripoll, M., Martinez Valle, R., 1999. Huesos neolitizacion y contextos arqueologicos aparentes. In: Bernabeu Auban, J., Orozco Köhler, T. (Eds.), Actes Del II Congres Del Neolitic a La Peninsula Iberica. Universitat de Valencia. 7-9 d'Abril, 1999. Universitat de Valencia, Valencia, Spain, pp. 589-596.

Bernabeu Auban, J., Barton, C.M., Perez Ripoll, M., 2001. A taphonomic perspective on neolithic beginnings: theory, interpretation, and empirical data in the western mediterranean. J. Archaeol. Sci. 28, 597-612. https://doi.org/10.1006/ jasc.2000.0591.

Bernabeu Auban, J., Orozco Köhler, T., Diez Castillo, A., Gómez Puche, M., Molina Hernández, F.J., 2003. Mas d'Is (Penàguila, Alicante): aldeas y recintos monumentales del Neolítico inicial en el valle del Serpis. Trab. Prehist. 60, 39-59. https://doi.org/10.3989/tp.2003.v60.i2.80.

Bernabeu Auban, J., Balaguer, L.M., Orozco Köhler, T., Diez Castillo, A., Barton, C.M. 2008. Early neolithic at the Serpis Valley, Alicante, Spain. In: Diniz, M. (Ed.) Early Neolithic in the Iberian Peninsula. \{BAR\} International Series. Archaeopress, Oxford, pp. 53-59.

Bernabeu Aubán, J., Martí Oliver, B., 2014. The first agricultural groups in the Iberian Peninsula. In: La Transition Néolitique En Méditerranée, pp. 419-438.

Bernabeu Aubán, J., Molina Balaguer, L. (Eds.), 2009. La Cova de les Cendres, Serie Mayo. ed.. Fundación MARQ Alicante. 
Bernabeu Aubán, J., Pascual Benito, J.L., Orozco Köhler, T., Badal Garcia, E., Fumanal García, P., García, O., 1994. Niuet (L’ Alqueria d' Asnar): poblado del III Milenio A.C. Recerques del Museu d'Alcoi 3, 9-74.

Bevan, A., Conolly, J., 2002. GIS, archaeological survey, and landscape archaeology on the island of kythera, Greece. J. Field Archaeol. 29, 123. https://doi.org/ $10.2307 / 3181488$.

Bevan, A., Conolly, J., 2006. Confronting scale in archaeology: issues of theory and practice. In: Lock, G., Molyneaux, B.L. (Eds.), Confronting Scale in Archaeology: Issues of Theory and Practice. Springer, New York, pp. 217-234. https://doi.org/ 10.1007/0-387-32773-8.

Bintliff, J., 2005. Human impact, land-use history, and the surface archaeological record: a case study from Greece. Geoarchaeology 20,135-147. https://doi.org/ 10.1002 /gea. 20040.

Buck, C.E., Sahu, S.K., 2000. Bayesian models for relative archaeological chronology building. J. Roy. Stat. Soc. C 49, 423-440. https://doi.org/10.1111/14679876.00203

Buck, C.E., Cavanagh, W.G., Litton, C.D., 1996. Bayesian approach to interpreting archaeological data. Statistics in practice xix +382.

Carey, C.J., Brown, T.G., Challis, K.C., Howard, A.J., Cooper, L., 2006. Predictive modelling of multiperiod geoarchaeological resources at a river confluence: a case study from the trent-soar, UK. Archaeol. Prospect. 13, 241-250. https:// doi.org/10.1002/arp.

Carrión, J., Van Geel, B., 1999. Fine-resolution upper weichselian and Holocene palynological record from navarres (Valencia, Spain) and a discussion about factors of mediterranean forest succession. Rev. Palaeobot. Palynol. 106, 209-236.

Carrión, J.S., Fernández, S., González-Sampériz, P., Gil-Romera, G., Badal, E., Carrión Marco, Y., López Merino, L., López Sáez, J.A., Fierro, E., Burjachs, F., 2010. Expected trends and surprises in the lateglacial and Holocene vegetation history of the iberian peninsula and balearic islands. Rev. Palaeobot. Palynol. 162, 458-475. https://doi.org/10.1016/j.revpalbo.2009.12.007.

Cherry, J.F., 1983. Frogs round the pond: perspectives on current archaeological survey projects in the Mediterranean region. In: Archaeological Survey in the Mediterranean Area, pp. 375-416.

Diez Castillo, A., García-Puchol, O., Bernabeu, J., Barton, C.M., Pardo-Gordó, S., Snitker, G., Cegielski, W., Bergin, S., 2016. Resiliencia y cambio durante el Holoceno en La Canal de Navarrés (Valencia): recientes trabajos de prospección. Archivo de Prehistoria Levantina XXXI 169-185.

Dunnell, R., 1992. The Notion of Site. Space, Time, and Archaeological Landscapes.

Dupré, M., Carrion, J.S., Fumanal, M.P., Roca, N.La, Martinez, J., Usera, J., 1998. Evolution and palaeoenvironmental conditions of an interfan area in eastern Spain (Navarrés, Valencia). Italian Journal of Quaternary Sciences 11, 97-105.

Fernández-López de Pablo, J., Barton, C.M., 2013. Bayesian estimation dating of lithic surface collections. J. Archaeol. Meth. Theor 559-583. https://doi.org/10.1007/ s10816-013-9198-z.

Fletcher Valls, D., Aparicio Perez, J., 1970. Exploraciones arqueologicas en el Barranco del Lobo, Chella (Valencia). Actas del XI C.A.N. 265-270.

Fletcher Valls, D., Pla Ballester, E., Llobregat Conesa, E., 1964. La Ereta del Pedregal (Navarrés, Valencia). Excavaciones Arqueol. Espana 42, 1-21.

Fortea Perez, J., 1971. La Cueva de la Cocina: ensayo de Cronología del Epipaleolitico, Servicio de Investigation Prehistorica Núm. 40.

García Atiénzar, G., 2009. Territorio Neolítico. Las primeras comunidades campesinas en la fachada oriental de la península Ibérica (ca. 5600-2800 cal BC). In: BAR International Series 2021

Garcia Borja, P., Salazar-García, D.C., Perez Fernandes, Á., Pardo Gordó, S., Casanova Vañó, V., 2011. El Neolítico antiguo cardial y la Cova de la Sarsa (Bocairent, Valencia): nuevas perspectivas a partir de su registro funerario (antiguo neolítico Cardial y La Cova de la Sarsa cueva (Bocairent, Valencia). Munibe. Antropol. Arqueol. 62, 175-195.

Garcia Guixé, E., Richards, M.P., Eulàlia Subirà, M., 2006. Palaeodiets of humans and fauna at the Spanish mesolithic site of el Collado. Curr. Anthropol. 47, 549-557.

García Puchol, O., Aura Tortosa, J.E., 2006. El Abric de la Falguera (Alcoí, Alacant). Diputación Provincial, Alicante.
García Puchol, O., Molina Balaguer, L., Aura Tortosa, J.E., Bernabeu Aubán, J., 2009. From the mesolithic ot the neolithic on the mediterranean coast of the iberian peninsula. J. Anthropol. Res. 65, 237-251.

García Puchol, O., Barton, C.M., Bernabeu Aubán, J., Diez Castillo, A., Pardo Gordó, S. 2014. De la prospección sistemática al laboratorio GIS en la Canal de Navarrés (Valencia). Saguntum 46, 209-214. https://doi.org/10.7203/ SAGVNTVM.46.4239.

García Puchol, O., McClure, S.B., Juan Cabanilles, J., Diez Castillo, A.A., Bernabeu Aubán, J., Martí Oliver, B., Pardo-Gordó, S., Pascual Benito, J.L., Pérez-Ripoll, M. Molina Balaguer, L., Kennett, D.J., 2017. Cocina cave revisited: Bayesian radiocarbon chronology for the last hunter-gatherers and first farmers in Eastern Iberia. Quat. Int. 1-13 https://doi.org/10.1016/j.quaint.2016.10.037.

Gibaja, J.F., Subirà, M.E., Terradas, X., Santos, F.J., Agulló, L., Gómez-Martínez, I., Allièse, F., Fernández-López de Pablo, J., 2015. The emergence of mesolithic cemeteries in SW europe: insights from the El Collado (Oliva, Valencia, Spain) radiocarbon record. PLoS One 10. https://doi.org/10.1371/journal.pone.0115505.

GRASS Development Team, 2016. Geographic Resources Analysis Support System (GRASS) Software [WWW Document]. Open Source Geospatial Foundation.

Juan Cabanilles, J., 1994. Estructuras de habitación en la Ereta del Pedregal (Navarrés, Valencia): resultos de las campañas de 1980-1982 y 1990. SAGVNTVM. Papeles del Laboratorio de Arqueología de Valencia 27, 67-97.

Juan Cabanilles, J., 2008. El utillaje de piedra tallada en la Prehistoria reciente valenciana. Aspectos tipológicos, estilísticos y evolutivos. Servicio de Investigación Prehistórica del Museo de Prehistoria de Valencia (Serie de Trabajos Varios, 109),. Diputación de Valencia, Valencia.

Llobera, M., Wilkinson, K.N., Weiss, M.C., Flaming, R.J., Marini, N.A.F., Mazet, S., 2010. Into the maquis: methodological and interpretational challenges in surveying la Balagne, northwest Corsica. J. Mediterr. Archaeol. 23, 169-196. https://doi.org/ 10.1558/jmea.v23i2.169.

Mallol, C., Hernández, C.M., Machado, J., 2012. The significance of stratigraphic discontinuities in Iberian Middle-to-Upper Palaeolithic transitional sites. Quat. Int. 275, 4-13. https://doi.org/10.1016/j.quaint.2011.07.026.

Martí-Oliver, B., 2011. La Cova de l’Or. In: Las Primeras Producciones Cerámicas: El VI Milenio Cal AC En La Península Ibérica. Universitat De València, Valencia, Spain, pp. 183-186

Martí Oliver, B., Tortosa, J.E.A., Cabanilles, J.J., García Puchol, O., Fernández-López de Pablo, J., 2009. El Mesolítico geométrico de tipo "Cocina” en el País Valenciano. In: El Mesolítico Geométrico En La Península Ibérica, pp. 205-258.

Ortman, S.G., Varien, M.D., Gripp, T.L., 2007. Empirical bayesian methods for archaeological survey data: an application from the mesa verde region. Am. Antiq. 72, 241-272. https://doi.org/10.2307/40035813.

Pardo Gordó, S., Diez Castillo, A., Bernabeu Aubán, J., 2009. Areas y suelos: el tamaño de los yacimientos de superficie. Una propuesta metodologica. SPATULE 18, 41-52. https://doi.org/10.12795/spal.2009.i18.03.

Pardo Gordó, S., Diez Castillo, A., Bernabeu Aubán, J., 2015. Prospecciones sistemáticas en la depressió de l'Alcoi (Alicante): analizando las colecciones superficiales. In: V Congresso Do Neolítico Peninsular.

Pla Ballester, E., Martí Oliver, B., Bernabeu Aubán, J., 1983. La Ereta del Pedregal (Navarrés, Valencia) y los inicios de la Edad del Bronce. In: Crónica Del XVI Congreso Arqueológico Nacional, pp. 239-248.

Riel-Salvatore, J., Barton, C.M., 2007. "Transitional” Upper Paleolithic Industries: New Questions, New Methods. "Transitional” Upper Paleolithic Industries: New Questions, New Methods, pp. 61-74.

La Roca, N., Fumanal, M.P., Martínez Gallego, J., 1996. Evolución Cuaternaria de Drenaje en un Corredor Intramontano: La Canal de Navarrés (Valencia, Spain). In: IV Reunión de Geomorfología, pp. 445-455.

Villaverde, V., Aura, J.E., Barton, C.M., 1998. The upper paleolithic in mediterranean Spain: a review of current evidence. J. World PreHistory 12, 121-198. https:/ doi.org/10.1023/A:1022332217614.

Villaverde Bonilla, V., Romána, D., Ripoll, M.P., Bergadà, M.M., Real, C., 2012. The end of the upper palaeolithic in the Mediterranean Basin of the iberian peninsula. Quat. Int. 272-273, 17-32. https://doi.org/10.1016/j.quaint.2012.04.025. 